\title{
From the classroom to the workplace: Three decades of evidence for Latin America
}

\author{
Mariana Viollaz
}

ABSTRACT

This study draws on household survey results spanning a period of three decades in length to analyse young people's entry into the labour market in 10 Latin American countries. It finds that: (i) the employment status of young people had deteriorated over time until seeing an improvement in the late 2000s, although youth unemployment and informality rates are still very high; (ii) young people are entering into a typical employment cycle in which they are surpassing the results obtained by adults of earlier generations. Informality is not a part of this pattern, however, indicating the existence of penalties associated with youth informality. Nonetheless, the outcomes are, for the most part, promising. The author concludes that efforts to improve the position of young people in the workforce should be continued in order to sustain the recent upturn in youth employment.

KEYWORDS

JEL CLASSIFICATION

AUTHOR
Young people, labour market, youth employment, working conditions, wages, gender, unemployment, employment statistics, Latin America

$\mathrm{J} 13, \mathrm{~J} 24, \mathrm{O} 17$

Mariana Viollaz is a junior researcher with the Centre for Distributive, Labour and Social Studies (cedLas) of the National University of La Plata, Argentina and a fellow of the National Council of Scientific and Technical Research (CONICET).mviollaz@cedlas.org 


\section{I}

\section{Introduction}

There has been growing concern in recent years about the deteriorating employment status of young entrants into the labour market. While youth employment is typically associated with limited job opportunities and high job turnover rates, successive increases in the youth unemployment rate and the existence of a large percentage of young people who are neither studying nor working have spurred interest in determining what underlying factors are driving this trend.

Youth is a stage in the working life cycle that is associated with limited job opportunities and job instability (Breen, 1992). Another typical characteristic of the position of young people in the workforce is high unemployment. A variety of reasons are often given for this situation. One possibility is that demographic changes may have increased the relative supply of young workers. Blanchflower and Freeman (2000) evaluate this hypothesis in a developed-country context but find no evidence of demographic effects in the increase in the youth unemployment rate witnessed during the 1990s. In the case of Latin America, the slowdown in population growth seen in the last two decades has had a favourable effect on youth employment (Weller, 2006; Fawcett, 2001). A decline in young people's level of education has also been advanced as a possible explanation for higher youth unemployment. However, Bell and Blanchflower (2010) find that young people in industrialized countries are more educated than they were before, and Bassi and Galiani (2009) and Weller (2006) report similar findings for Latin America. Other explanations focus on changes in labour institutions and shifts in the sectoral structure of the job market that work to the detriment of the sectors that are the main employers of young workers. Minimum wage laws may, for example, discourage employers from hiring people in this age group (Neumark and Nizalova, 2007). The introduction of new technologies tends to increase the demand for skilled labour, which could have an impact on the recruitment of young people (Dolado, Felgueroso and Jimeno, 2000). Another important factor that hinders

$\square$ The author is grateful for the comments and very helpful suggestions concerning an earlier version of this study made by an anonymous referee. many young people in the Latin American region from successfully entering the labour market is the sharp inequalities that mark young people's opportunities for human and social capital formation (Weller, 2006).

There are a number of different theories about why young people's position in the workforce is also so unstable. The "job shopping" theory suggests that many young people's job transitions are voluntary because they are taking advantage of the stage in their working lives when the opportunity cost is low to move from one occupation to another in search of better options (Neumark, 2002). Some degree of instability could also stem from frequent entries and exits from the labour force associated with human capital formation. On the other hand, high labour turnover in the younger segment of the population could be an involuntary phenomenon linked to characteristics of the individuals concerned and of the workplaces where they are employed. For example, because young people have less work experience than their older counterparts, they are often in a more vulnerable position, since the direct and indirect costs of dismissing them are lower than they would be in the case of workers with more seniority. In addition, young people are often employed in low-productivity activities in which the opportunities to gain expertise in a given area are much more limited (Maurizio, 2011).

Earlier studies have shown that economic and labour conditions in the 1990s and the early 2000s were not conducive to the entry of young workers into the labour force in Latin America (Weller, 2006). This study will extend the period of analysis up to the end of the 2000s. The data that are available for this longer period will provide a basis for analysing recent trends in labour indicators pertaining to the young population. This will make it possible to determine whether the employment prospects for young people have improved in recent years or whether unfavourable conditions have persisted despite the growth of Latin American economies during this period.

To that end, as part of this study a detailed analysis of various labour indicators has been undertaken for 10 countries of the region. The countries selected for this purpose, based on the availability of the relevant information, were: Argentina, Brazil, Chile, Costa Rica, El Salvador, Honduras, Mexico, Panama, Uruguay and 
the Bolivarian Republic of Venezuela. ${ }^{1}$ The data used in this analysis were drawn from the Socio-Economic Database for Latin America and the Caribbean (SEDLAC), which contains household survey data for the countries of Latin America and the Caribbean and is maintained by the Centre for Distributive, Labour and Social Studies (CEDLAS) of the National University of La Plata and the World Bank. Table 1 shows the information available for each country and period of analysis, while table A.1 (see the appendix) details the household surveys that were the source of those data. The information is divided up into six periods corresponding to the early and later years of each decade. The only exception to this is the last period, for which information from the latest available surveys was also included.

For the purposes of this study, young people will be defined as persons between the ages of 15 and 24, while those between the ages of 25 and 65 will be classified as adults. The labour statistics used here are averages for the 10 countries covered by the study. This average

1 Taken together, the populations of these countries represented $74 \%$ of the total population of Latin America as of 2012 (World Bank, 2012). is arrived at by weighting the results for each country on the basis of the share of the total population that its population represents in each period. In order to avoid giving a disproportionate weight to countries for which more information was available, a single year within each period was selected, with an effort being made to use the same year for all of the countries (see table A.2 in the appendix). It follows that the results computed on the basis of weighted averages will be skewed towards the countries with larger populations. In order to determine if the results are primarily reflecting the trends in those countries, the simple averages are also given and the cases in which the results for those simple averages differ from the weighted averages will be discussed.

This study is structured as follows. Section II briefly reviews the trends in labour supply relating to young adults in Latin America and their characteristics. Section III looks at various indicators that provide information about the labour market for young and adult workers over the past three decades; this information is broken down by sex and level of education. Section IV presents a pseudo-panel analysis using birth cohorts in order to shed light on the behaviour of these indicators once the persons concerned enter adulthood. Section V concludes with some closing remarks and policy proposals.

TABLE 1

Available surveys

\begin{tabular}{|c|c|c|c|c|c|c|}
\hline Country & Early $1980 \mathrm{~s}$ & Late $1980 \mathrm{~s}$ & Early 1990s & Late $1990 \mathrm{~s}$ & Early 2000 s & Late 2000 s \\
\hline Argentina & 1980 & $1985-1989$ & 1990-1994 & 1995-1999 & $2000-2004$ & $2005-2012$ \\
\hline Brazil & 1981-1984 & 1985-1989 & 1990, 1992-1993 & 1995-1999 & 2001-2004 & 2005-2009, 2011 \\
\hline Chile & $\ldots$ & 1987 & 1990, 1992, 1994 & 1996, 1998 & 2000,2003 & 2006, 2009, 2011 \\
\hline Costa Rica & $\ldots$ & 1989 & 1990-1994 & 1995-1999 & 2000-2004 & $2005-2010$ \\
\hline El Salvador & $\ldots$ & $\ldots$ & 1991,1993 & $\begin{array}{l}1995,1996 \\
1998,1999\end{array}$ & $2000-2004$ & $2005-2010$ \\
\hline Honduras & $\ldots$ & $\ldots$ & 1990-1994 & 1995-1999 & $2001-2004$ & $2005-2011$ \\
\hline Mexico & $\cdots$ & 1989 & 1992 & 1996, 1998 & $\begin{array}{c}2000,2002 \\
2004\end{array}$ & $\begin{array}{l}2005-2006 \\
2008,2010\end{array}$ \\
\hline Panama & $\ldots$ & 1989 & 1991 & 1995, 1997, 1998 & 2001-2004 & $\begin{array}{l}2005-2006 \\
2009-2012\end{array}$ \\
\hline Uruguay & $\ldots$ & 1989 & 1992 & 1995-1999 & 2000-2004 & $2005-2011$ \\
\hline $\begin{array}{l}\text { Venezuela (Bolivarian } \\
\text { Republic of) }\end{array}$ & $\ldots$ & 1989 & 1992 & 1995, 1998, 1999 & 2000-2004 & $2005-2011$ \\
\hline
\end{tabular}

Source: Socio-Economic Database for Latin America and the Caribbean (SEDLAC) of the Center for Distributive, Labor and Social Studies (CEDLAS) and the World Bank. 


\section{II}

\section{The youth labour supply}

The growth rate of the young population in Latin America has been slowing since the early 1980s. While the young population grew by $11 \%$ between 1980 and 1985, it rose by just $1 \%$ between 2005 and 2010. And while it is true that the growth rate of the working-age population as a whole (persons between 15 and 65 years of age) has also been declining, the decrease has not been nearly as sharp (see figure 1).

The figures reflect the ageing of the working-age population in Latin America: whereas young people accounted for $36 \%$ of the working-age population in the early 1980 s, that figure had dropped to $27.5 \%$ by the late 2000 s.

In terms of levels of education, the proportion of the young population with no more than a primary education has fallen steeply. In the early 1980s, primary education was the highest level reached by $72 \%$ of all young people, but this figure had plummeted to $26 \%$ by the late 2000 s, with a commensurate rise in the percentage of young people with a secondary or higher education during the three decades under study (see figure 2).
The lengthening of the period during which investments in human capital are being made can also be observed by analysing the distribution of young people in Latin America in terms of their status as students and/ or workers. The proportion of the young population that is studying and not working increased by 10 percentage points during the period under study, with a reduction of a similar magnitude being seen in the proportion who are working and not studying; during the same period, the proportion of young people who are neither studying nor working shrank by 5 percentage points. ${ }^{2}$ The proportion who both study and work increased, as did the percentage of unemployed youths (see figure 3 ).

This first brief overview of the trends in the young labour force in Latin America shows that this age group

\footnotetext{
2 Although the percentage of young people who are not in school and are not working has shrunk, the size of this group in absolute terms is nonetheless quite large. Cárdenas, de Hoyos and Székely (2011) analyse its members' characteristics and the reasons for the persistence of this phenomenon.
}

FIGURE 1

Young population in Latin America, 1980-2010 (Millions of people)

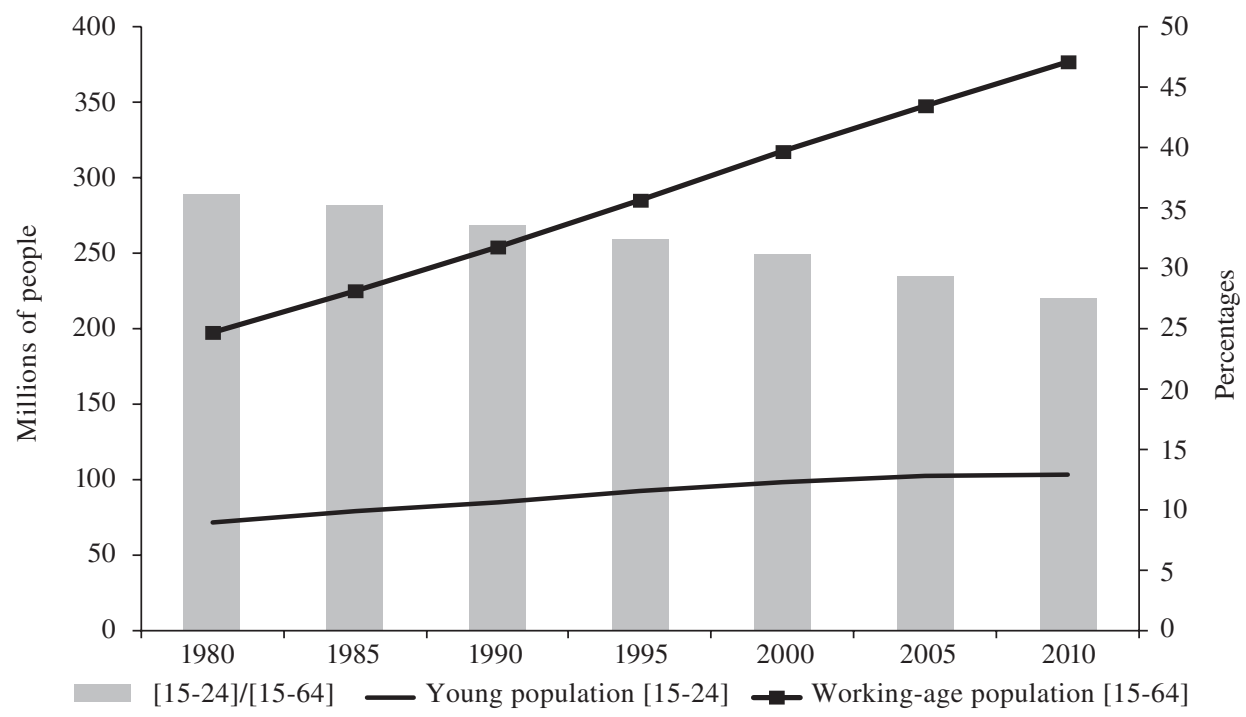

Source: prepared by the author on the basis of Databases and Statistical Publications (CEPALSTAT) of the Economic Commission for Latin America and the Caribbean (ECLAC). 
FIGURE 2

Young people's level of education

(Average for Latin America)

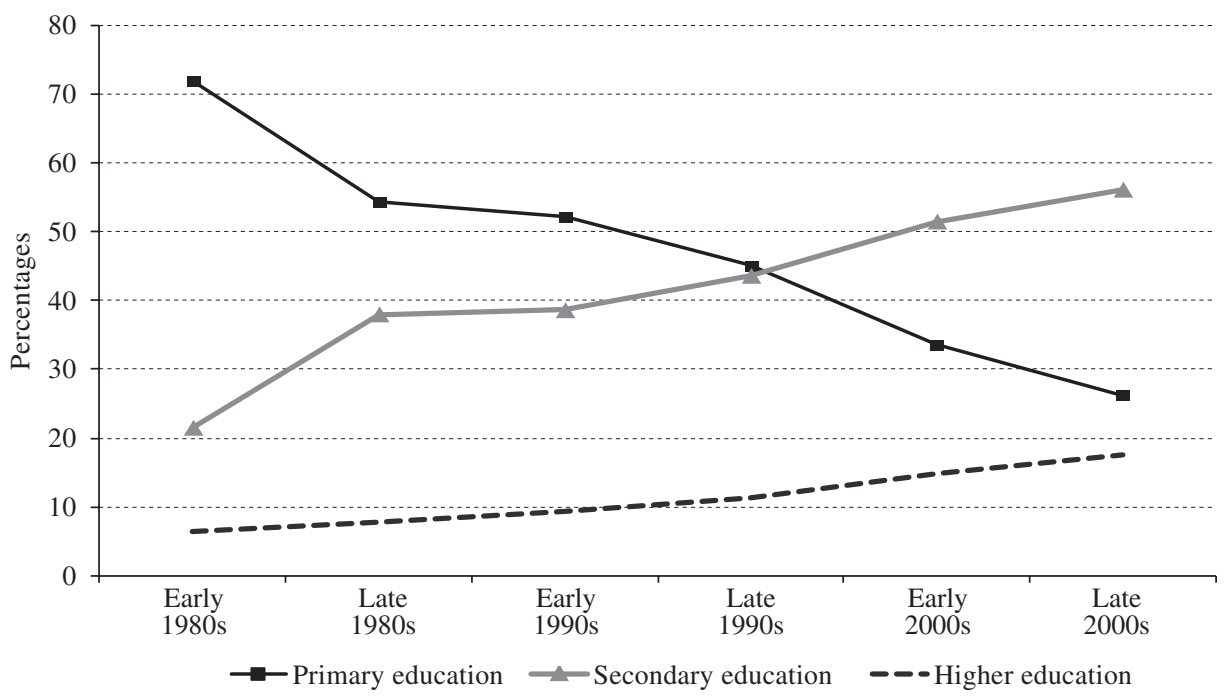

Source: prepared by the author on the basis of the Socio-Economic Database for Latin America and the Caribbean (SEDLAC) of the Center for Distributive, Labor and Social Studies (CEDLAS) and the World Bank.

FIGURE 3

Distribution of the young population, by schooling and employment status (Average for Latin America)

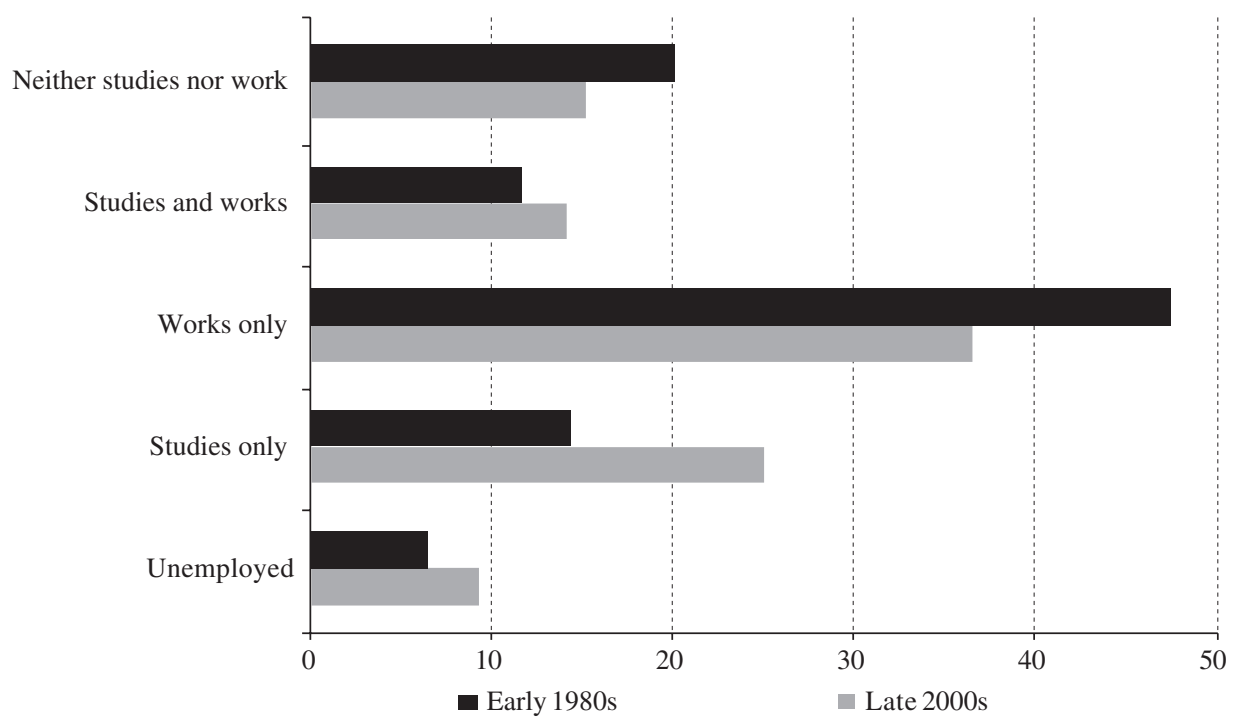

Source: prepared by the author on the basis of the Socio-Economic Database for Latin America and the Caribbean (SEDLAC) of the Center for Distributive, Labor and Social Studies (CEDLAs) and the World Bank.

makes up a smaller and smaller portion of the region's working-age population. It also shows that young people's level of education has risen considerably over the period in question, and despite this, their unemployment rate has climbed as well.
The high rate of youth unemployment is a trend that is not confined to Latin America. The ratio between the youth unemployment rate and the nationwide unemployment rate took a turn for the worse during the 1990s in other world regions as well (see figure 4). 
A. $1990-1994$

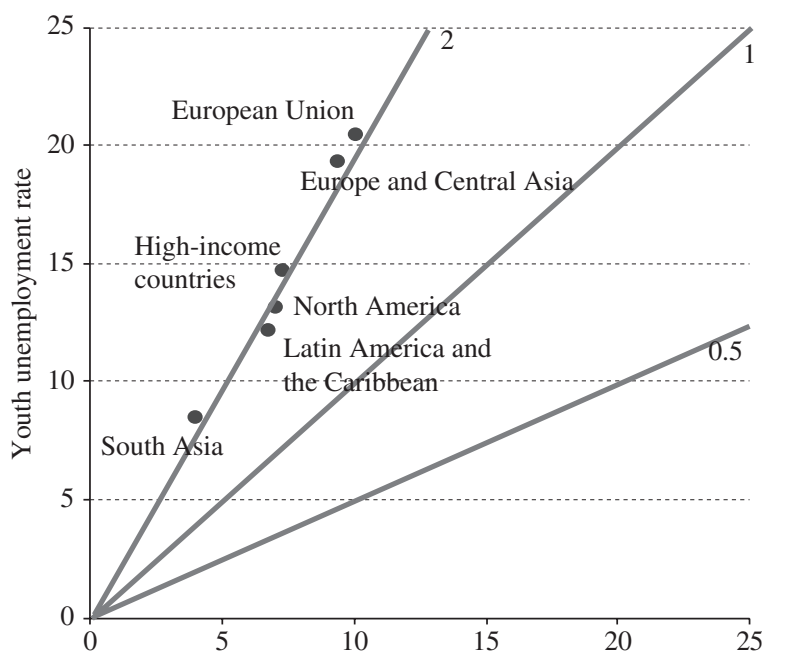

B. $2005-2009$

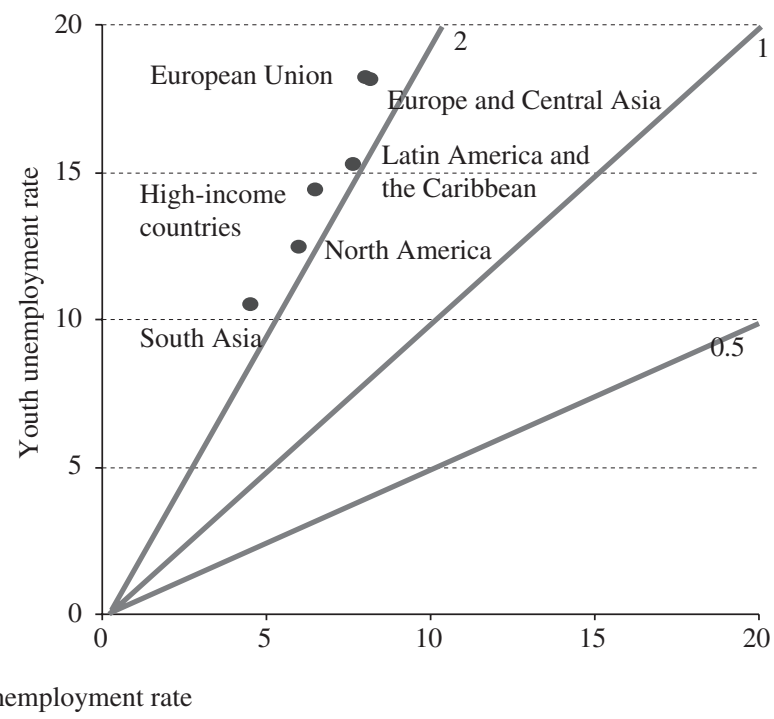

Source: prepared by the author on the basis of World Bank, World Development Indicators.

At that time, the Latin American region had one of the lowest indicators in this respect (youth unemployment was $83 \%$ higher than the nationwide rate), but it also witnessed one of the sharpest deteriorations in this ratio during that time and exhibited the steepest increase in youth unemployment.

\section{III}

\section{Employment status of young people in Latin America}

\section{Participation and labour market integration}

The labour-force participation rate for young Latin Americans has declined since the early 1980s. The trend in the adult population has been just the opposite, so the gap between the two groups' participation rates has widened during this period (see table A.3 in the appendix). The left-hand panel of figure 5 traces the movement of this indicator when it is calculated as a weighted average. For the first part of this period, information is available only for Argentina and Brazil, while the sample for the late 1980s can be expanded to include Chile, Costa Rica, Mexico, Panama, Uruguay and the Bolivarian Republic of Venezuela. In order to show how much of the change seen between the early and late 1980s is attributable to the expansion of the sample, the dotted lines denote what the value for this indicator would be in the late 1980s if the observations were confined to Argentina and Brazil. The expansion of the sample thus leads to a drop in the activity rate for young people. This is accounted for by the addition of Chile and the Bolivarian Republic of Venezuela, whose youth participation rates are far below those of Argentina and Brazil for this period. ${ }^{3}$ When the

\footnotetext{
3 The statistics for the individual countries are available and will be supplied by the author upon request.
} 
indicator is computed as a simple average, the level and trend remain much the same for adults but the values for young people fall (see the right-hand panel in figure 5).

One possible explanation for this downturn in the young population's participation rate may lie in the extension of the period of investment in human capital. The proportion of young people who are studying and not working rose by $67 \%$ during the period in question and amounted to one fourth of the young population of Latin America by the late 2000s. As a result, the percentage of young people with no more than a primary education shrank and the percentage with a secondary or higher education rose. In the case of the adult population, the increase in the participation rate can be accounted for by the entry of more women into the workforce. Table A.4 of the appendix shows that the participation rate for adult men remained steady at around $91 \%$, while the rate for women jumped from $40 \%$ in the early 1980 s to $61 \%$ by the late 2000 s. When the rates for young people are disaggregated by sex, we see that the drop in this group's participation rate was concentrated among men, with the rate for women rising slightly.

Restricting the sample to people who are not attending school provides a way of controlling for the extension of the period of investment in human capital (see table A.5 in the appendix). In this case, the youth participation rate does not exhibit any large fluctuations but instead remains around an average of $73 \%$. This is higher than the rate for the young population as a whole, which reflects the choices made between the vying options of studying and working (Marchionni, Bet and Pacheco, 2007), and is actually higher than the participation rate for adults in the 1980s and 1990s. It follows from these figures that approximately $30 \%$ of the young people who are not studying are not working or actively seeking work either. When the data are disaggregated by sex, it can be seen that the participation rate remained at around $90 \%$ for men and climbed from $50 \%$ to $60 \%$ for women. This difference is undoubtedly associated to some extent with the performance of unpaid domestic work and care for family members by women.

The trend in the youth employment rate is similar to the trend in the youth participation rate (see figure 6). Youth employment levels dropped significantly during the period under study, while just the opposite occurred in adult employment levels, although the youth employment rate did recover slightly between the early and late 2000s. Here again, the addition of other countries to the sample in the late 1980s leads to a lower employment rate than the rate that is registered for Argentina and Brazil alone. As a result, the calculation of the indicator as a simple average yields a lower employment rate.

The hypothesis has been advanced that the drop in the labour-force participation rate for young people can be accounted for by increased investment in human capital. But what about the young people who remained
A. Weighted average

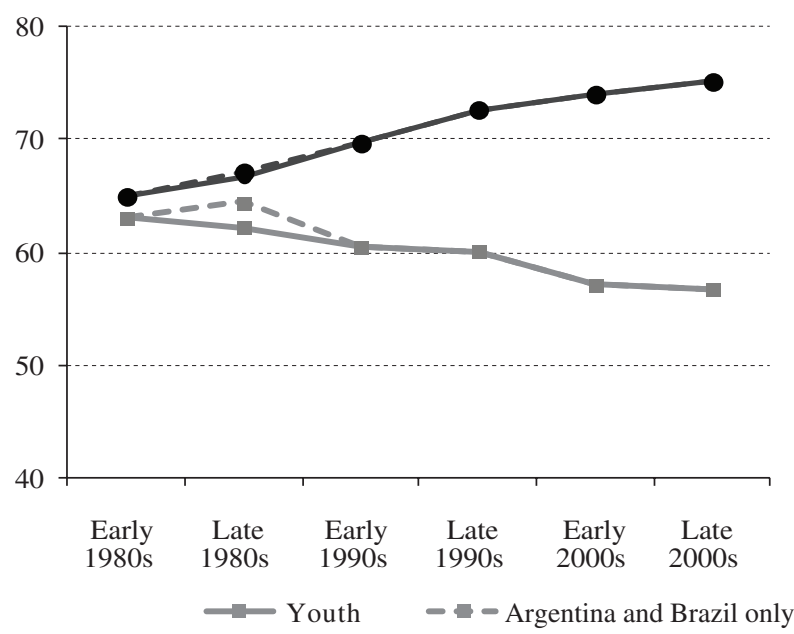

B. Simple average

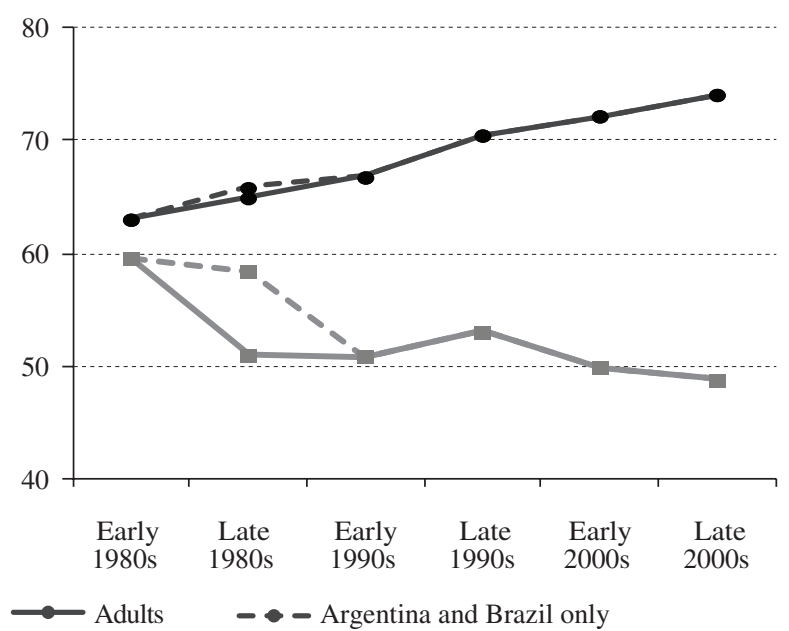

Source: prepared by the author on the basis of the Socio-Economic Database for Latin America and the Caribbean (SEDLAC) of the Center for Distributive, Labor and Social Studies (CEDLAS) and the World Bank. 
A. Weighted average

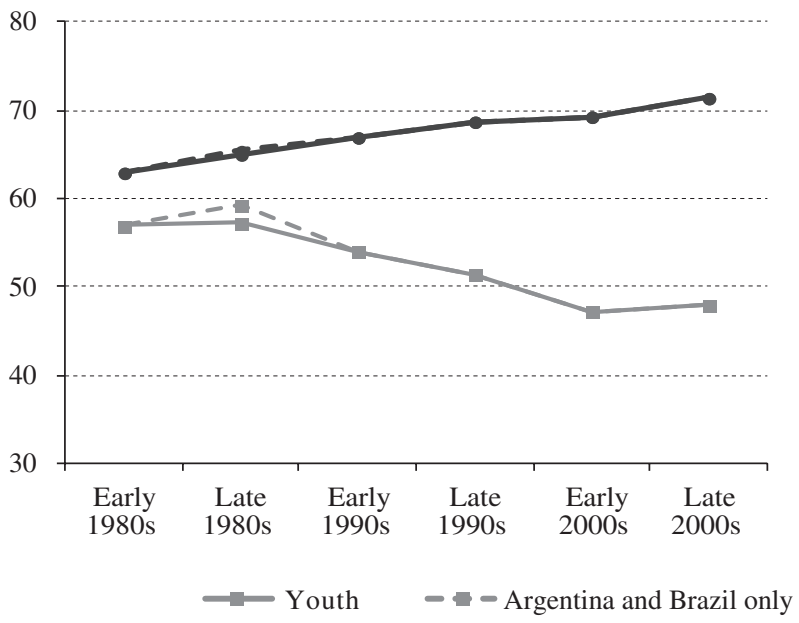

B. Simple average

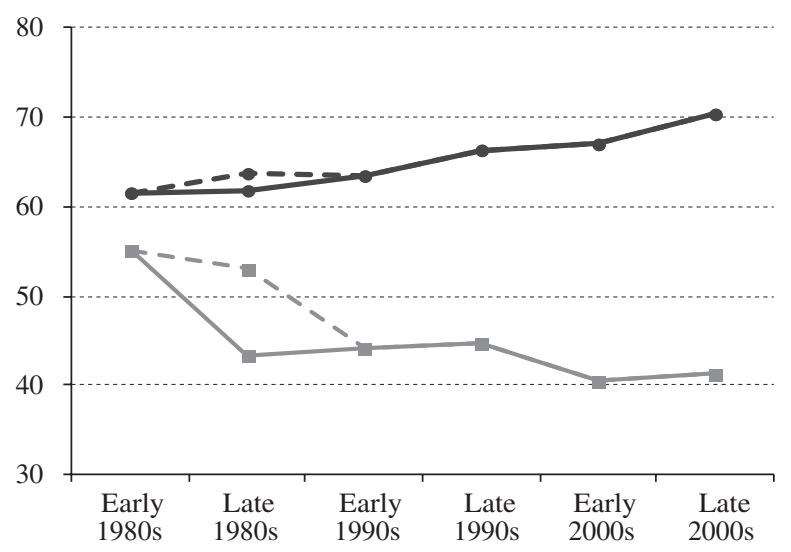

Source: prepared by the author on the basis of the Socio-Economic Database for Latin America and the Caribbean (SEDLAC) of the Center for Distributive, Labor and Social Studies (CEDLAS) and the World Bank.

in the labour market and were not studying? When the sample is restricted to people who were not attending an educational institution, the youth employment rate was higher than it was for the young population as a whole, but it still declined over the period under study. At this point, something quite interesting can be observed. When the sample is reduced by excluding people who are studying, the youth participation rate remains steady, rather than declining as it did for the larger sample, but the employment rate remains on a downward trend, although a less steep one, with a recovery then being noted between the early and late 2000s. When the figures are disaggregated by level of education, it can be seen that the drop in formal-sector employment was greater for young people with primary or secondary educations than for those with a higher education (see table A.7 in the appendix). In the latter portion of the period under study, these overall trends changed, with the decline in the employment levels of less-educated young people levelling off, an upswing being registered for those with a secondary education and a slight reduction in the rate for those with a higher education. When the figures are disaggregated by sex, we see that the drop in employment occurred only among men, while the employment level for women increased, especially during the latter part of the period under analysis. This provides clear evidence of an increase in the number of unemployed young people among those who are not accumulating human capital, with a possible improvement towards the end of the period under study.

The trend in the youth unemployment rate is a major problem in the labour markets of the region. Between the late 1980s and the early 2000s, the youth unemployment rate doubled. It then began to descend, as did the adult unemployment rate (see figure 7). When the indicator is computed as a simple average, we see that the expansion of the sample for the late 1980s triggers a sudden change owing to the addition of the high youth unemployment rates in "small" countries such as Chile, Panama and Uruguay. In the early 1990s, this indicator improved for those countries, thereby giving way to a similar trend to that obtained for the indicators when calculated using figures weighted by the size of the population, although the rate was somewhat higher.

While these values are averages of starkly different situations across countries, the comparisons of the figures nonetheless show that, during the latter portion of this period, the youth unemployment rate was more than double the nationwide unemployment rate in 7 out of the 10 countries concerned. The exceptions are Honduras, El Salvador and the Bolivarian Republic of Venezuela, where the youth unemployment rates in the late 2000s were $78 \%, 88 \%$ and $92 \%$ higher than the rate for adults, respectively. In all the countries considered, unemployed youths represent between 37\% (Bolivarian Republic of Venezuela) and 54\% (Honduras) of the total number of unemployed persons (see figure 8). 
FIGURE 7

\section{Unemployment rate}

(Average for Latin America)

A. Weighted average

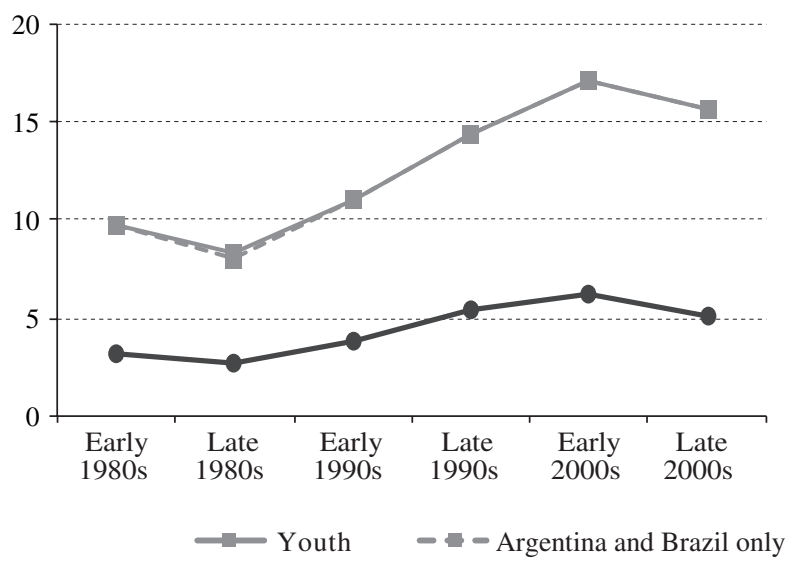

B. Simple average

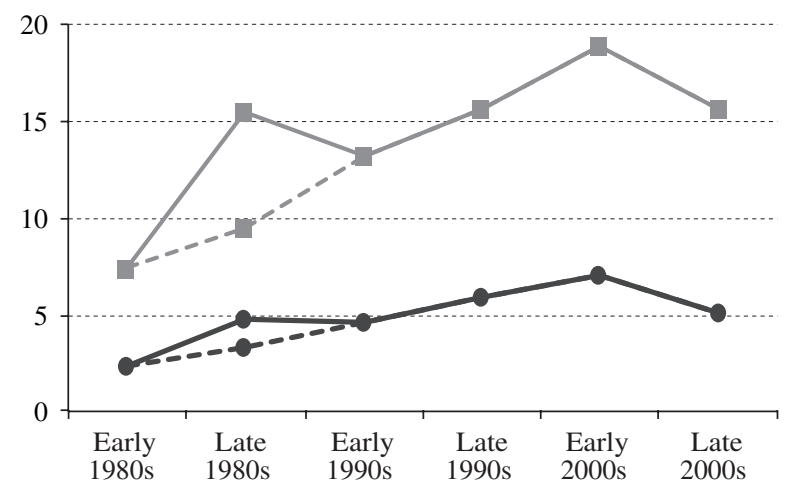

Source: prepared by the author on the basis of the Socio-Economic Database for Latin America and the Caribbean (SEDLAC) of the Center for Distributive, Labor and Social Studies (CEDLAS) and the World Bank.

FIGURE 8

Nationwide unemployment as compared to youth unemployment

(Late 2000s)

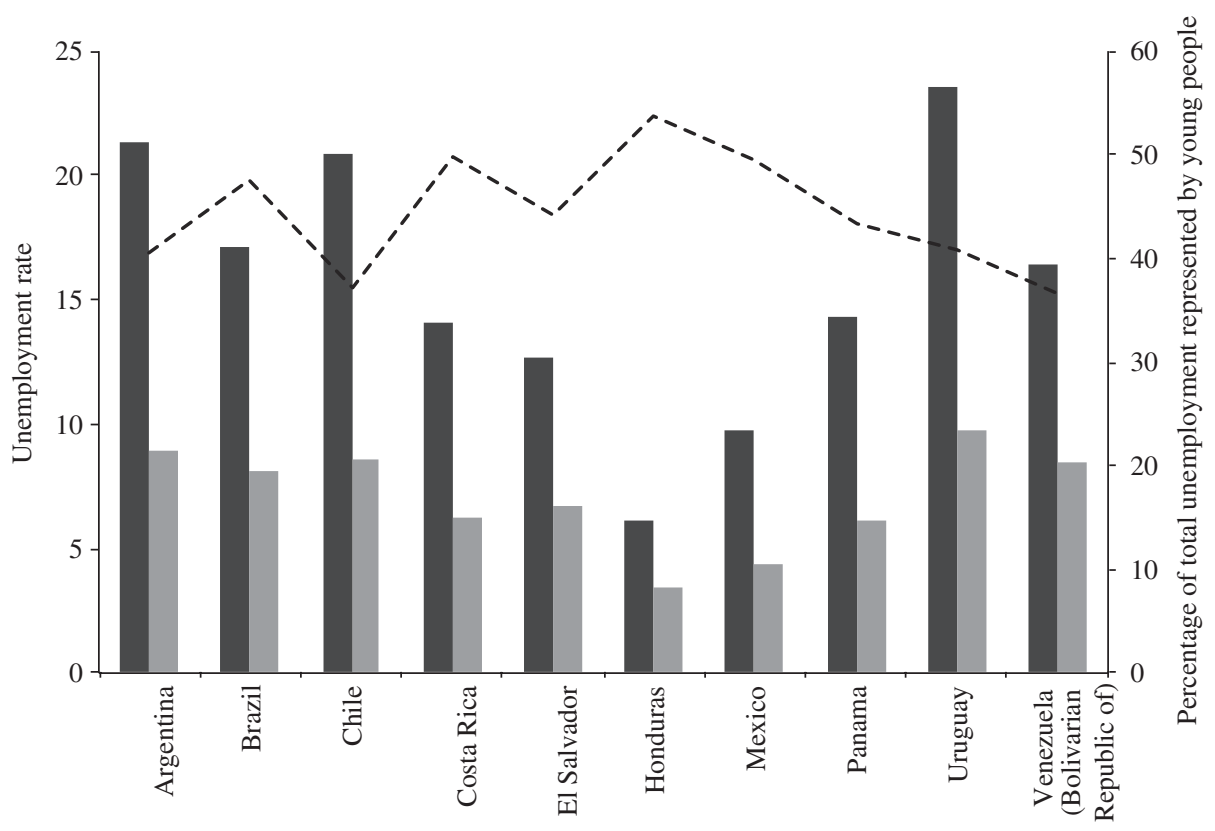

Youth unemployment rate Nationwide unemployment rate _- _. Percentage of total unemployment represented by young people

Source: prepared by the author on the basis of the Socio-Economic Database for Latin America and the Caribbean (SEDLAC) of the Center for Distributive, Labor and Social Studies (CEDLAS) and the World Bank. 
By restricting the sample to people who are not attending school, we can isolate the cases in which unemployment is attributable to engagement in a competing activity (studies). In this case, we find a similar trend in the youth unemployment rate but at a lower level than in the full sample. When the figures are disaggregated by sex, we see that unemployment is lower among men. A disaggregation by levels of education turns up a number of patterns: (i) unemployment rates rose for all levels of education but then improved in the late 2000s; (ii) youth unemployment trends follow an inverted u-curve as a function of the level of education for all periods (see figure 9); and (iii) unemployment rates for young people with a higher education were slightly higher than the rates for young people with primary educations except in the 1980s.

There may be two possible explanations for this last trend. The first has to do with an involuntary aspect of the job turnover rate for young people. Employers offering highly skilled jobs often require that candidates have experience in performing the tasks involved, and young people have a harder time fulfilling that requirement. Highly educated young people may also have difficulty in finding a job because low-productivity activities account for a larger share of youth employment (Maurizio, 2011). This second possible explanation has to do with a voluntary aspect of job turnover. The search for a "good match" may take longer for more educated youths, since they will be trying to find a position that is in line with their qualifications.

The inverted u-curve for youth unemployment and level of education could be related to the increase in the number of young people who have completed their secondary education (see figure 2). However, this ratio is evident for all periods, not just the 2000s, which is when the proportion of young people with a secondary education surpassed the proportion of those with no more than a primary education. The explanation would therefore appear to lie in labour demand. The activities that are the largest employers of young workers tend to be low-productivity activities that generate a demand for less-educated workers. The demand for more highly skilled young workers is thought to be smaller, but, then, so is the supply. Workers with a secondary education are therefore in a segment for which demand is low and supply is on the rise.

The length of time spent unemployed is higher for adults. Figure 10 depicts the distribution of three categories of unemployed persons: those who have been unemployed for up to 6 months; those who have been unemployed for a period lasting between 6 months and 1 year; and those who have been looking for work for more than 1 year. In the 1980s, unemployed youths were concentrated in the first two categories; from the 1990s on, the distribution became polarized between the shortest and longest periods of unemployment. The
A. Weighted average

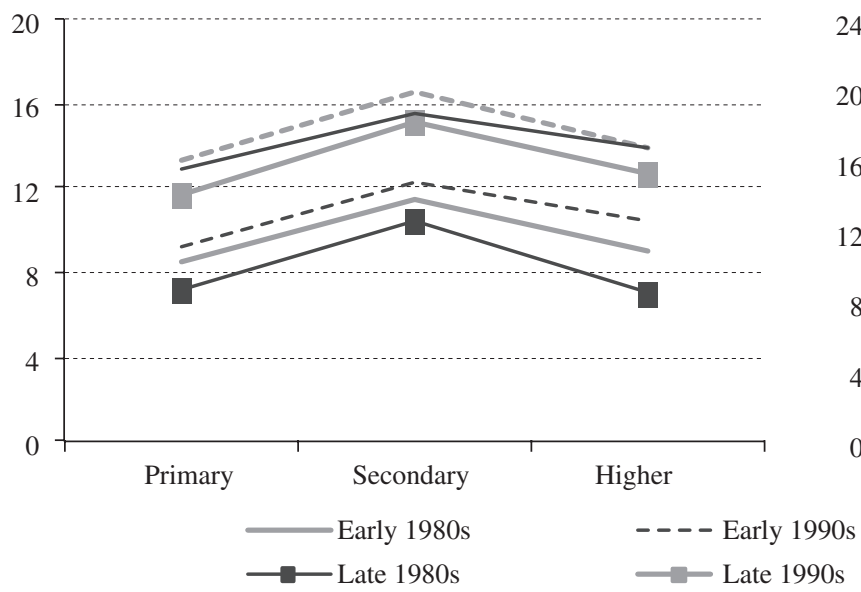

B. Simple average

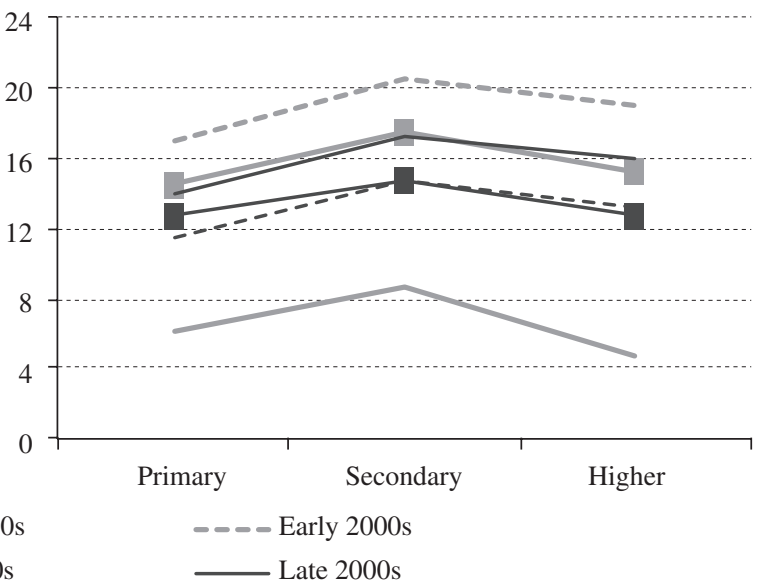

Source: prepared by the author on the basis of the Socio-Economic Database for Latin America and the Caribbean (SEDLAC) of the Center for Distributive, Labor and Social Studies (CEDLAS) and the World Bank. 
FIGURE 10

Distribution of the unemployed population, by duration of unemployment (Average for Latin America)

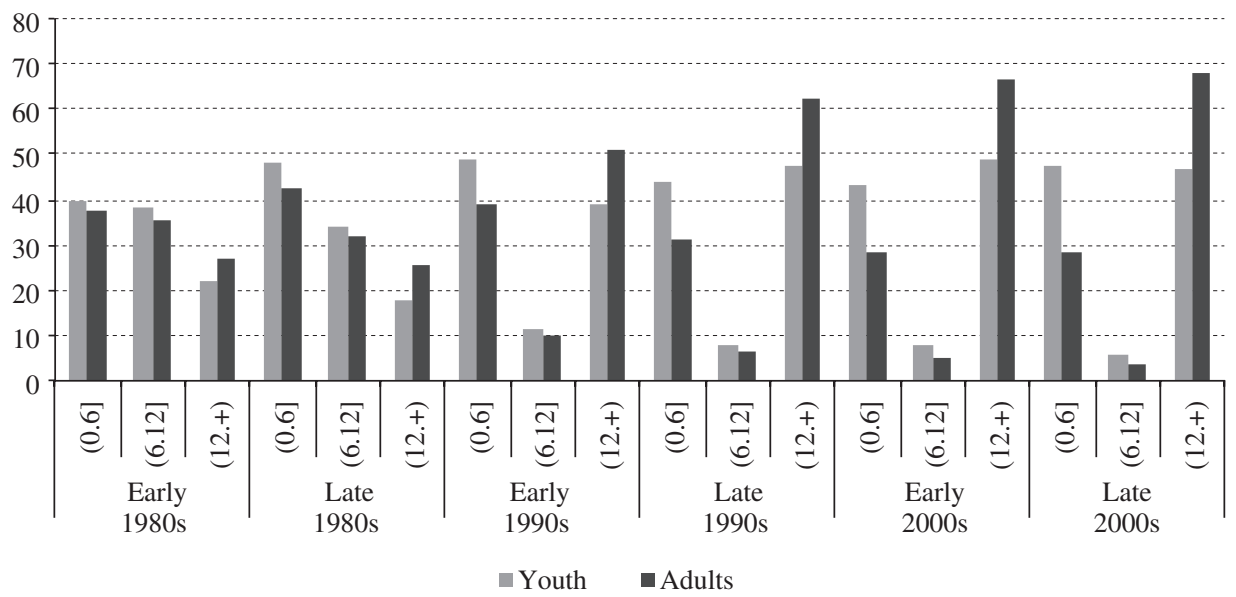

Source: prepared by the author on the basis of the Socio-Economic Database for Latin America and the Caribbean (SEDLAC) of the Center for Distributive, Labor and Social Studies (CEDLAS) and the World Bank.

Note: $(\mathrm{x}, \mathrm{y})$ interval does not include the two extreme values for $\mathrm{x}$;

$(\mathrm{x}, \mathrm{y}]$ interval excludes the lowest value for $\mathrm{x}$ and includes the highest value for $\mathrm{y}$.

distribution for the unemployed adult population is similar but with a slightly larger proportion of adults falling into the longest-duration category than in the case of young people. This result appears to be counter-intuitive, since young job-seekers are at a disadvantage because they have less work experience. It is important to remember, however, that the length of time that a person has been unemployed is reported at the time that the survey was taken, so the overall duration of unemployment is not known. It follows that young workers who have spent relatively little time in the labour market will also have been unemployed for less time. Another possible reason for this gap is the existence of differing preferences on the part of job seekers. Young people who are only recently entering the job market are not fully aware of what types of positions may be available and may rotate between different types of occupations, interspersed with fairly brief periods of unemployment between one job and the next. Adults who have a better understanding of the job market and who have more clearly defined preferences may take longer to find a job that is a good match for them.

\section{Youth employment characteristics}

The percentage of people who would like to change jobs or work more hours is a subjective indicator of employment status. This figure has invariably been higher for young people, on average, in Latin America, although the level and trend of this indicator vary across countries. In Brazil, Costa Rica, Honduras and the Bolivarian Republic of Venezuela, it has trended upward. In Panama, it has trended downward. And in Argentina and Uruguay, this indicator rose until the late 2000s and then began to decline. ${ }^{4}$

The informality rate — defined as the percentage of jobs performed by people who are not registered with the social security system — has invariably been higher for young people, with the differential between young and adult workers traditionally being around 20 percentage points. The trend has been moving upward for both age groups, with a slight recovery for young people towards the end of the 2000s. It is difficult to gauge the welfare implications of informal employment for young workers. If they continue to be listed as dependents of an adult (the head of household, for example), they may have social security coverage if that person is working in the formal sector of the economy. ${ }^{5}$ Otherwise, informal employment while young may influence people's ability to position themselves in the labour market later on by either increasing the likelihood that they will remain in the informal sector as adults or by lowering their wage-

4 Information for this indicator for Chile, Mexico and El Salvador is not available.

5 In most Latin American countries, a formal-sector worker can provide social security coverage (e.g., health insurance) to his or her family members (primarily the spouse and children). 
level prospects if informality is interpreted as a sign of low productivity (Cruces, Ham and Viollaz, 2012).

There is a clear-cut negative correlation between the informality rate and level of education (see table A.6 in the appendix). Young workers with no more than a primary education are the worst off: the differential between the informality rate for young people with primary educations and those with secondary educations amounts to 26 percentage points, while the gap between those with a secondary education and those with a higher education totals 37 points. The decline in the informality rate for the young population in the late 2000s is wholly accounted for by the drop in the rate for people with a higher education.

The rising rate of youth unemployment, coupled with the rising informality rate for this age group, suggests that young people are entering the informal sector because they are running up against some sort of barrier to entry into the formal sector of the economy and that this barrier is particularly difficult for less-educated youths to overcome. The evidence of rising skill levels runs counter to the idea that educational differentials account for the higher informality rate among young people. On the other hand, we would appear to be witnessing an occupational segregation process whereby employment in jobs that do not afford social security coverage is being taken up by young workers to a disproportionate degree.

The hourly wage (in purchasing power parity (PPP) dollars at 2005 prices) has always been higher for adults. This is to be expected, since years of work experience increase with age. The wage differential peaked in the late 1990s, when an adult worker was earning, on average, US\$2.00 per hour more than a young worker. The wage gap separating young and adult workers increases as their level of education rises, with the differential being less than US $\$ 1.00$ for people with a primary level of education, US\$2.00 for people with a secondary education and US\$ 5.00 for persons with a higher education. Another interesting point is that the wage gap, as a regionwide average, has narrowed for less-educated young people.

Wage differentials for young people corresponding to different levels of education differ from one country to the next (see table 2).

In Argentina, Chile and Costa Rica, the differential has fluctuated around 1.4. Uruguay is the only country in which this ratio increased over time. Brazil, El Salvador and Panama registered downturns, while in Mexico and the Bolivarian Republic of Venezuela, the wage ratio between skilled and unskilled young workers has fluctuated up and down.

The differential in the number of hours worked by young and adult workers decreased over the period under study, with the number of hours worked by young people dropping somewhat more than the number registered for adult workers. At the start of the 1980s, the gap in the number of hours worked was 0.7 hours (with the larger figure being registered for adults), while at the end of the 2000s, the figure had climbed to 2.1 hours. More highly educated adults and young people both work fewer hours, on average, than their counterparts who have not completed their primary or secondary education.

Youth: wage differentials by educational level, early 1980s-late 2000s (Quotients) $^{\mathrm{a}}$

\begin{tabular}{lcccccc}
\hline & Early 1980s & Late 1980s & Early 1990s & Late 1990s & Early 2000s & Late 2000s \\
\hline Argentina & & & & & & \\
$\quad$ Mean & $\ldots$ & 1.417 & 1.305 & 1.401 & 1.385 & 1.399 \\
$\quad$ Standard error & $\ldots$ & 0.005 & 0.002 & 0.001 & 0.002 & 0.001 \\
Brazil & & & & & \\
$\quad$ Mean & 2.444 & 2.476 & 2.236 & 1.905 & 1.696 & 1.490 \\
$\quad$ Standard error & 0.001 & 0.002 & 0.001 & 0.001 & 0.001 & 0.001 \\
Chile & & & & & \\
$\quad$ Mean & $\ldots$ & $\ldots$ & 1.396 & 1.398 & 1.244 & 1.321 \\
$\quad$ Standard error & $\ldots$ & $\ldots$ & 0.004 & 0.007 & 0.003 & 0.004 \\
Costa Rica & $\ldots$ & 1.486 & 1.491 & 1.477 & 1.577 & \\
$\quad$ Mean & & 0.008 & 0.003 & 0.004 & 0.004 & 0.002 \\
$\quad$ Standard error & & & & & & \\
\hline
\end{tabular}


Table 2 (conclusion)

\begin{tabular}{|c|c|c|c|c|c|c|}
\hline & Early 1980 s & Late $1980 \mathrm{~s}$ & Early 1990s & Late $1990 \mathrm{~s}$ & Early 2000s & Late $2000 \mathrm{~s}$ \\
\hline \multicolumn{7}{|l|}{ El Salvador } \\
\hline Mean & $\ldots$ & $\ldots$ & 1.996 & 1.599 & 1.374 & 1.401 \\
\hline Standard error & $\ldots$ & $\ldots$ & 0.022 & 0.003 & 0.002 & 0.002 \\
\hline \multicolumn{7}{|l|}{ Honduras } \\
\hline Mean & $\ldots$ & $\ldots$ & 2.298 & 1.878 & 1.924 & 1.782 \\
\hline Standard error & $\ldots$ & $\ldots$ & 0.009 & 0.004 & 0.005 & 0.005 \\
\hline \multicolumn{7}{|l|}{ Mexico } \\
\hline Mean & $\ldots$ & $\ldots$ & 1.887 & 1.724 & 1.935 & 1.518 \\
\hline Standard error & $\ldots$ & $\ldots$ & 0.003 & 0.001 & 0.002 & 0.001 \\
\hline \multicolumn{7}{|l|}{ Panama } \\
\hline Mean & $\ldots$ & $\ldots$ & 1.693 & 1.519 & 1.566 & 1.420 \\
\hline Standard error & $\ldots$ & $\ldots$ & 0.012 & 0.008 & 0.004 & 0.003 \\
\hline \multicolumn{7}{|l|}{ Uruguay } \\
\hline Mean & $\ldots$ & 1.227 & 1.256 & 1.292 & 1.346 & 1.410 \\
\hline Standard error & $\ldots$ & 0.006 & 0.007 & 0.004 & 0.004 & 0.004 \\
\hline \multicolumn{7}{|c|}{ Venezuela (Bolivarian Republic of) } \\
\hline Mean & $\ldots$ & 1.447 & 1.539 & 1.783 & 1.567 & 1.218 \\
\hline Standard error & $\ldots$ & 0.002 & 0.003 & 0.004 & 0.007 & 0.001 \\
\hline
\end{tabular}

Source: Socio-Economic Database for Latin America and the Caribbean (SEDLAC) of the Center for Distributive, Labor and Social Studies (CEDLAS) and the World Bank.

a Quotients of the hourly wage of skilled young workers (workers who have completed their secondary or higher education) and the hourly wage of unskilled young workers (workers who have an incomplete secondary education or less).

\section{Employment outcomes for young people as viewed from a gender perspective}

The way in which males and females position themselves in the labour market differs, as do their employment outcomes. Generally speaking, women are confronted with less favourable working conditions than men because of the difficulties they have in combining gainful employment with the work that they are called upon to do in the home, and because of the gender-based discrimination and segregation to which they are subject in Latin American labour markets (Maurizio, 2010).

As noted earlier, the drop in the participation rate for young people over the period under study is accounted for by the lower activity rate for men. An increasing number of women, on the other hand, have been entering the workforce, although in absolute terms there are still fewer women than men in the labour market. Employment rates for both young men and young women are continuing to fall, however.

At this point it will be useful to analyse the distribution of young men and women in terms of their schooling and employment status. Figure 11 shows that the gender-based distributions differ substantially, even though the trends for the two categories have moved in the same direction. For young men, the largest category is "works and does not study", even though it declined from $63 \%$ in the early 1980 s to $46 \%$ in the late 2000 s. For women, the largest categories were "works and does not study" and "neither works nor studies", with percentages ranging from over $30 \%$ to around $25 \%$ at the close of this period. The proportion of young women who studied but did not work and the proportion of young women who were unemployed consequently rose. These changes in trends notwithstanding, the percentage of young women who confine their activity to domestic tasks continues to be far greater than the corresponding figure for men.

Youth unemployment rates for both men and women have been rising, although the unemployment rate for women has consistently been higher than the rate for men. Young men and women have both had informality rates of around $50 \%$, but the upswing in this indicator was sharper in the case of men between the late 1980s and the early 2000s. Hourly wages trended upward for both sexes, but the upturn was so much sharper in the case of young women that the wage gap had been closed by the early 2000 s. 
A. Men

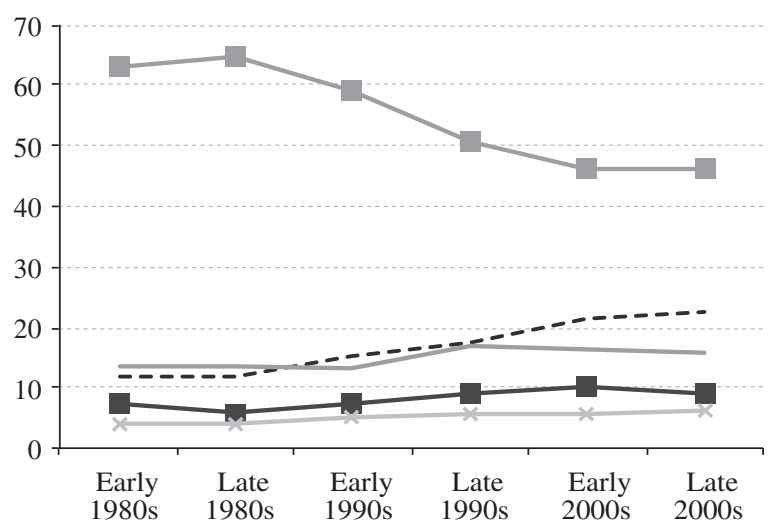

B. Women

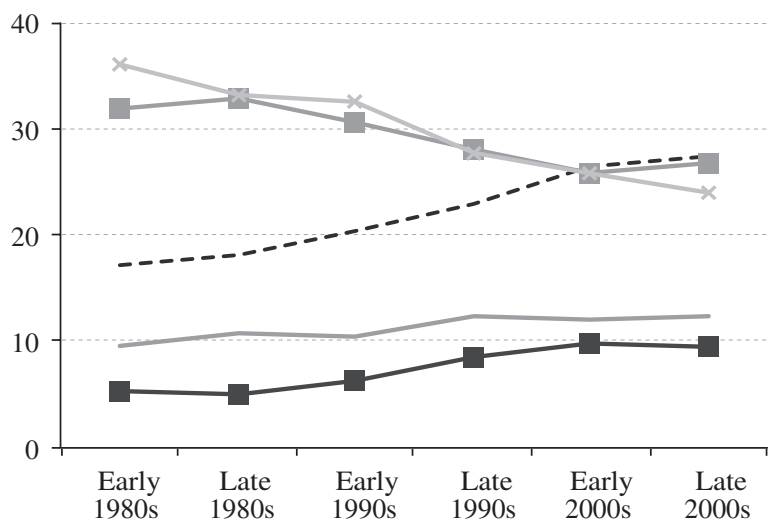

$\longrightarrow$ Unemployed ---- Studying only —-Working only Studying and working

Neither studying nor working

Source: prepared by the author on the basis of the Socio-Economic Database for Latin America and the Caribbean (SEDLAC) of the Center for Distributive, Labor and Social Studies (CEDLAS) and the World Bank.

\section{IV}

\section{Analysis of the working life cycle}

The aim of this section is to analyse labour market dynamics in Latin America in order to see what labour indicators may have to tell us about the course of the working life cycle. The idea is to discern behavioural patterns that do not show up in cross-section analyses. For example, we will try to see if the difficulties encountered by young people who are just entering the labour market persist once they have reached adulthood and if this situation changes as time goes on or not. The job instability experienced by young people during their early years in the labour market may have an impact on their future employment prospects. For example, it is possible that young people who were unemployed during that stage in their working life may be penalized in the sense that they may be more likely to be unemployed when they are adults as well.

The available information cannot be structured as panel data. The proposed methodology therefore involves defining birth cohorts and following their behaviour over time (see table 3 ). Based on the available information for the 10 countries covered in this study, 6 cohorts were constructed. The first is made up of people born during the first half of the 1960s, who were then observed between the time that they were 16 years old and the time that they reached the age of 49 . The second cohort is composed of people born in the second half of that decade, who were observed between the time that they were 15 years of age and the time that they reached the age of 44 . The third, fourth and fifth cohorts were constructed in a similar way. Their members were observed from the time that they were 15 years old up to a given point in their adult life. The time span covered is inevitably shorter for the younger cohorts. People born in the second half of the 1980s make up the sixth and last cohort, for which observations are available only for the period during which they were young. The averages for the region as a whole have been weighted on the basis of each country's share in the relevant age group, such that, for each cohort and each age group, the weightings equal unity. The indicators were also computed as simple averages for all the countries in order to control for the influence of those with larger populations.

Figure 12 depicts the labour-force participation and employment rates for three of the cohorts and seven age intervals. These are the oldest cohort (born between 1960 and 1964), an intermediate cohort (born between 1970 
TABLE 3

Birth cohorts

(By age intervals)

\begin{tabular}{lcccccc}
\hline Cohorts & Early 1980s & Late 1980s & Early 1990s & Late 1990s & Early 2000s & Late 2000s \\
\hline $1960-1964$ & $16-24$ & $21-29$ & $26-34$ & $31-39$ & $36-44$ & $41-49$ \\
$1965-1969$ & $15-19$ & $16-24$ & $21-29$ & $26-34$ & $31-39$ & $36-44$ \\
$1970-1974$ & & $15-19$ & $16-24$ & $21-29$ & $26-34$ & $31-39$ \\
$1975-1979$ & & & $15-19$ & $16-24$ & $21-29$ & $26-34$ \\
$1980-1984$ & & & & $15-19$ & $16-24$ & $21-29$ \\
$1985-1989$ & & & & & $15-19$ & $16-24$ \\
\hline
\end{tabular}

Source: prepared by the author.

FIGURE 12

Labour-force participation and employment rates for three birth cohorts (Weighted average)

A. Participation rate

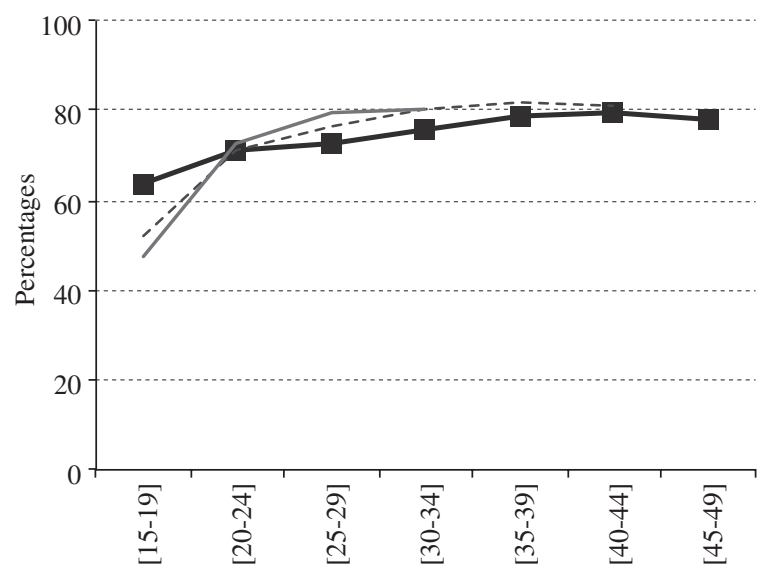

1960-1964
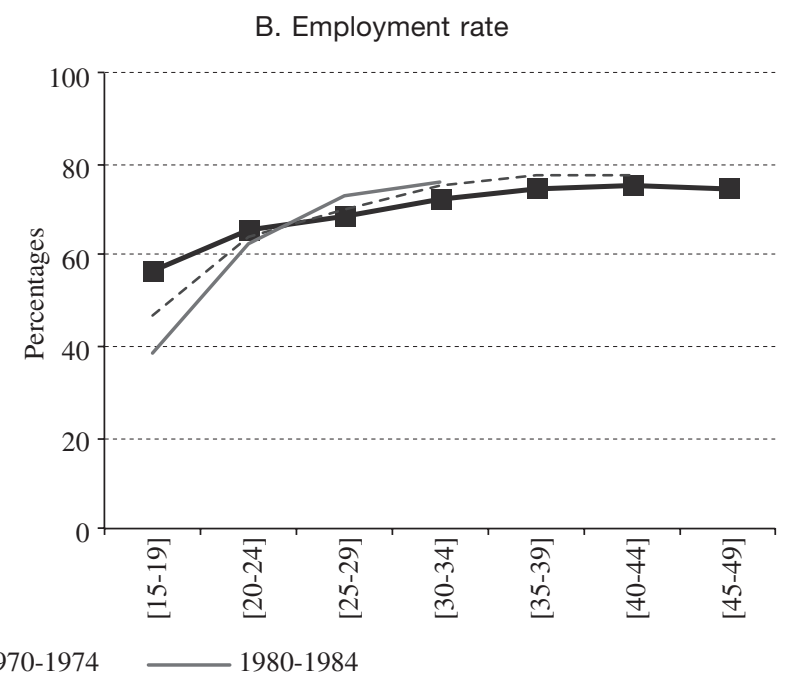

Source: prepared by the author on the basis of the Socio-Economic Database for Latin America and the Caribbean (SEDLAC) of the Center for Distributive, Labor and Social Studies (CeDlas) and the World Bank.

Note: $[\mathrm{x}, \mathrm{y}]$ interval includes both extremes.

and 1974) and a younger cohort (born between 1980 and 1984). This approach is used as a means of simplifying the picture so that the main behavioural patterns captured by the labour indicators can be discerned. The detailed results for each of the cohorts are shown in table A.8 in the appendix.

The inter-cohort differences observed in the first age groups reflect the pattern analysed in section III. Activity and employment rates are lower for the more recent cohorts, especially for the 15-19 age group. In the next age group, participation and employment rates rise and the differentials between cohorts begin to narrow. The members of all the cohorts display a typical working life cycle, whereby participation and employment rates for young people increase as they age but at a descending pace. The evidence provided by this type of analysis indicates that the ranking of the cohorts is reversed once the members of those cohorts become adults. Once they have reached the age of 25 , their participation and employment rates are higher than those of the adults in earlier cohorts. This same pattern emerges when the results are computed as a simple average. When the figures are disaggregated by sex, it can be seen that, for men, the inter-cohort differential begins to narrow as they reach adulthood and thereafter hardly varies at all. In the case of women, the upturn in activity and employment rates is faster. Starting with the 20-24 age group, the youngest cohort surpasses 
its predecessors, and this pattern remains in evidence throughout the labour life cycle (see table A.9 of the appendix). The disaggregation by level of education shows that the upswing for the most recent cohort occurs more slowly for people with a higher education (see table A.10 of the appendix).

The unemployment rate for young people in the most recent cohort is far higher than the rate for young people in earlier cohorts (see the left-hand panel of figure 13). ${ }^{6}$ As the members of the cohorts continue their careers, their unemployment rate drops. The unemployment rate for the 1970-1974 birth cohort matches the rate for the oldest cohort when its members reach 34-39 years of age and is lower thereafter. The unemployment rate for the 1980-1984 birth cohort drops more steeply and matches the rate for the 1970-1974 birth cohort upon entry into adulthood. The analysis also shows that people born between 1980 and 1984 had very high unemployment rates during their youth but have since then made a very

6 Inter-cohort differentials are even sharper when simple averages are used and reflect the differences existing across countries. fast recovery during adulthood. The patterns for men and women are similar, although the unemployment rate for men is lower. The analysis by levels of education reveals similar patterns, with higher unemployment rates for people with secondary and higher educations, which fits in with the findings discussed in section III. The members of younger cohorts who have no more than a primary education have improved upon the performance of earlier generations, but this pattern is not seen in the groups with a secondary or higher education when weighted averages are computed. ${ }^{7}$

Hourly wages positively correlate with age in all birth cohorts (see the right-hand panel in figure 13). Increases in wages are also apparent in younger cohorts, especially when the 1980-1984 birth cohort is compared with earlier cohorts. This fits with the analysis discussed in section III, which shows that the wages of young people and adults trend upward over time. Here again, wage trends for men and women are much the same,

7 Improvements in wage levels for all educational categories are seen when simple averages are used, however.

Unemployment rate and average hourly wage for three birth cohorts (Weighted average)

A. Unemployment rate

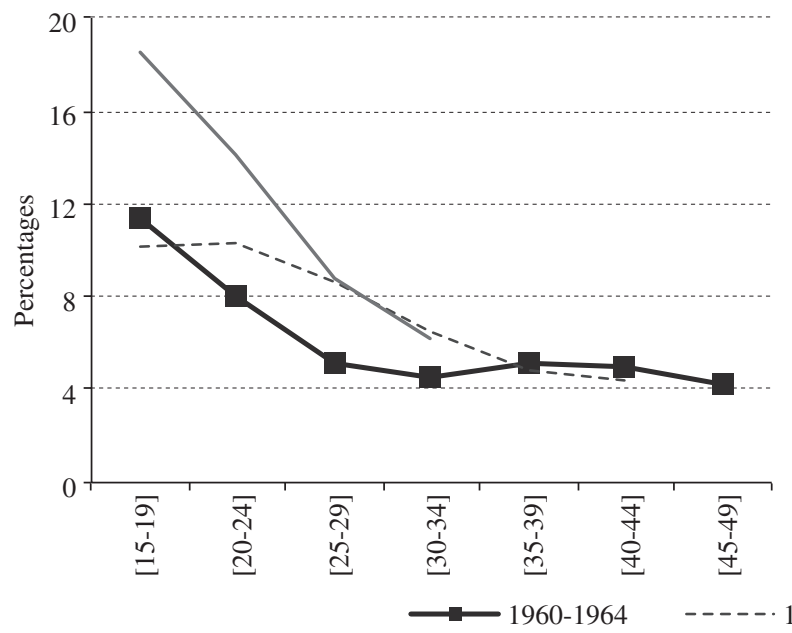

B. Hourly wage

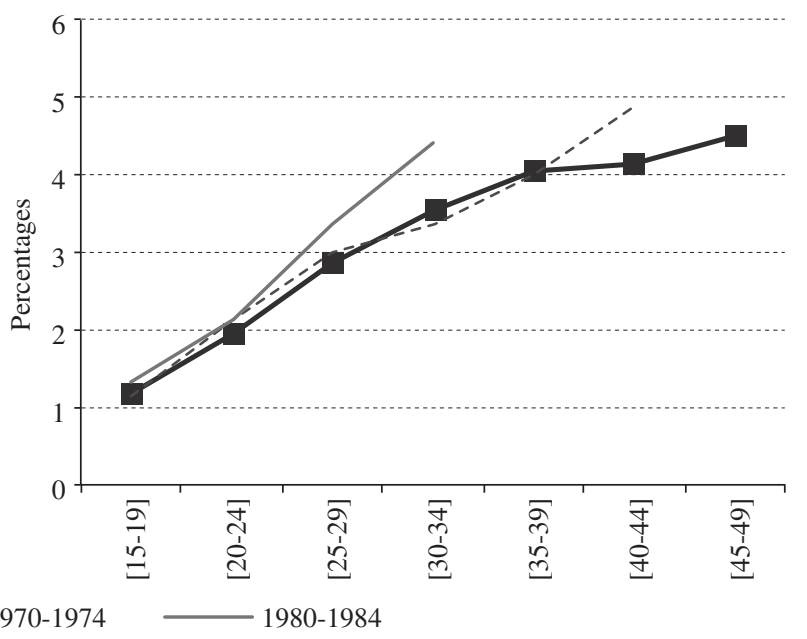

Source: prepared by the author on the basis of the Socio-Economic Database for Latin America and the Caribbean (SEDLAC) of the Center for Distributive, Labor and Social Studies (CEDLAS) and the World Bank.

Note: $[\mathrm{x}, \mathrm{y}]$ interval includes both extremes. 
but the level of wages is higher for men. This pattern is also seen in the wages earned by people with no more than a primary education, which are lower than the wage levels recorded for the sample as a whole. The upswing for people with a secondary education is slower, and wage levels for the members of the youngest cohort who have a higher education never do reach the levels of older cohorts.

The last indicator that will be examined in this section is the informality rate. The analysis depicted in figure 14 indicates, first of all, that informal employment decreases with age until the first years following entry into adulthood, after which it begins to increase over time. In section III, we saw that the informality rate for adults was consistently lower than the rate for young people but that the rate for adults increased more sharply over time than the rate for young people did. The U-curve pattern that emerges from the cohort analysis reflects this phenomenon. Secondly, it shows that, when more recent cohorts were examined, the rate of informality was higher at all stages in the working life cycle. Thirdly, it suggests that the gap is tending to narrow during adulthood for the most recent cohort, which succeeds in matching the performance of the preceding cohort but which is still a long way from attaining the levels reached by the oldest cohort. This holds for both men and women and may be signalling that some sort of penalty is associated with employment in the informal sector during one's youth. Fourthly, the results disaggregated by level of education show that the informality rate for members of the most recent cohort who have a higher education drops sharply to levels close to that of the 1970-1974 cohort by 30-34 years of age. Members of the most recent cohort who have completed no more than their primary or secondary educations reduce their informality rate as they gain work experience, but they do not actually manage to close the gap between them and the 1970-1974 cohort. The penalty associated with employment in the informal sector during one's youth would appear to be greater in these cases.

FIGURE 14

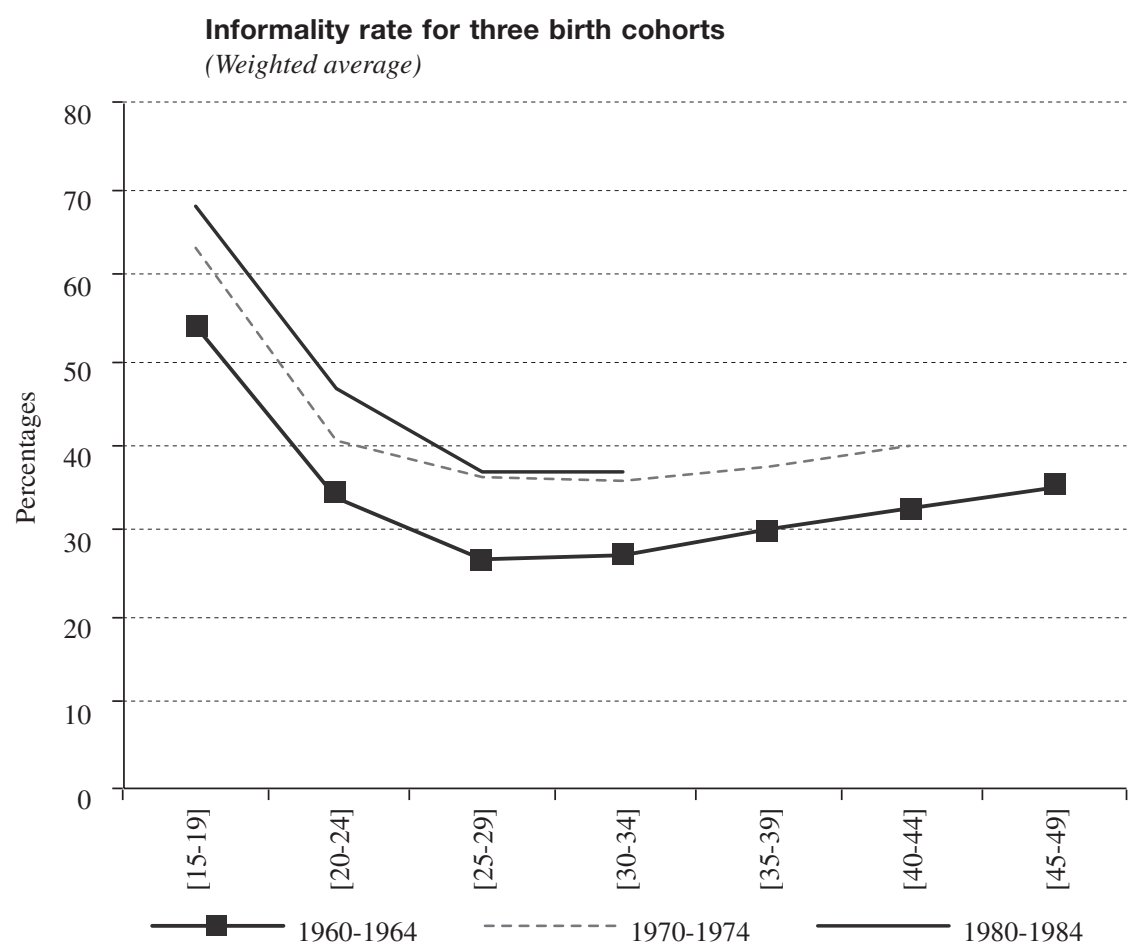

Source: prepared by the author on the basis of the Socio-Economic Database for Latin America and the Caribbean (SEDLAC) of the Center for Distributive, Labor and Social Studies (CEDLAs) and the World Bank.

Note: $[\mathrm{x}, \mathrm{y}]$ interval includes both extremes 


\section{$\mathrm{V}$}

\section{Conclusions}

This study has focused on a range of characteristics and patterns in Latin American labour markets over the last three decades. The analysis of trends in labour indicators shows that the employment status of young people had deteriorated over time but then began to improve in the late 2000s. The amount of time required to make the transition from the stage of human capital formation to the stage at which entry into the labour market takes place has increased because the first of those stages now covers a longer time span, but the employment status of the young people who remain in the labour market has worsened. Despite the improvement in young people's qualifications, their unemployment and informality rates have risen, which indicates that new formal-sector entry barriers have arisen or existing ones have become more formidable, and these barriers are particularly difficult for less-educated young people to surmount. This suggests that the efforts made to improve young people's position in the labour market should be continued with a view to prolonging the upswing seen towards the end of the period under study.

The analysis also indicates that young people whose prospects are somewhat dim when they first try to enter the workforce eventually manage to enter into a typical working life cycle as they gain more work experience. As a result, young people in the more recent birth cohorts are achieving higher employment rates during adulthood, as well as lower unemployment rates and better hourly wages than the adults belonging to previous cohorts. The more recent cohorts' rate of informality declines as they pass into adulthood, but the more recent generations are not succeeding in matching the performance of older generations. This indicates that there is some type of penalty associated with employment in the informal sector during one's youth. This phenomenon is concentrated among people with no more than a primary education. While it is true that informal employment can provide a person with on-the-job training and work experience (Bosch and Maloney, 2010; Cunningham and Bustos, 2011), this analysis shows that the kind of training and work experience acquired in the informal sector during people's youth may not be enough to propel them into formal-sector jobs in their adulthood (Cruces, Ham and Viollaz, 2012).

An analysis undertaken from a gender perspective shows that young women are entering the labour market, but that the proportion who neither study nor work remains far above the proportion of young men in that situation. And for those who are active participants in the labour market, the unemployment rate is also higher than the rate for men. The brighter employment prospects for young people that emerged in the late 2000s had a strong impact on women in some cases, with both the uptrend in wages and the reduction in the informality rate being sharper for women than for men.

To sum up, the results indicate that the dim prospects facing young people on the verge of entering the labour market during the 1990s and early 2000 s began to brighten in the late 2000s. In addition, the working life cycle analysis shows that young people's position in the labour market improves once they become adults. While these findings are very promising, it is important to remember that this improvement in young people's employment status takes time, and that the nature of their positions in the labour market may be associated with penalties during their adult years in terms of lower wages, fewer job opportunities or a reduced ability to obtain work in the formal sector of the economy.

In view of the fact that the deterioration in the employment status of young people seen up to the early 2000s occurred despite the fact that these young people were more educated than their predecessors, it is clear that policies aimed at helping people to obtain their first job are called for. The high rate of informality for this group and recent evidence that employment in the informal sector during one's youth may not provide sufficient training to allow a person to transition into the formal sector of the economy (Cruces, Ham and Viollaz, 2012) add another policy challenge into the equation. Monetary incentives for the recruitment of young workers or a reduced minimum wage for this age group may lower what employers may perceive as the high cost of hiring such workers and thereby encourage them to hire young people. Another possible strategy would be to lower the cost of seeking employment by, for example, providing transportation subsidies that would make it more affordable for job seekers to travel from their place of residence to areas where formal jobs are located.

The combination of the young population's high unemployment rate and that population's rising level of education calls the quality of the region's education 
systems into question. Latin America has made major strides in recent decades in opening up access to education, but a greater degree of segmentation in terms of educational outcomes and the quality of instruction has also been noted (ECLAC, 2011). In the presence of unequal access to educational opportunities, it can be expected that social inequities may persist and even worsen during the transition from the classroom to the workplace. Measures designed to broaden and strengthen education in the early years of schooling and provide vocationally appropriate instruction could provide a way of smoothing the transition from the classroom to the workplace while ensuring that new entrants will be able to adapt to changes in production activities and technologies.

Another employment strategy would be to facilitate business start-ups or other independent production activities. Reducing the limitations that hinder unemployed persons from starting up a business or an economic activity of their own (by, for example, doing away with legal barriers and loan constraints) would be another way of assisting young people to make this transition.

All policies in this area should also take into account the differences in the employment opportunities and conditions of men and women and be crafted in such a way as to do away with discriminatory practices in the labour market.

In conclusion, improvements in the quality of young people's first experience in the labour market should be a priority. While it is true that the labour market's growing instability runs counter to young people's need for some degree of job continuity (Weller, 2006), policy measures that can strengthen young people's position in terms of job stability and job quality can have lasting positive effects on these people's working life cycles. 
APPENDIX

TABLE A.1

\section{Household surveys}

\begin{tabular}{|c|c|c|}
\hline Argentina & $\begin{array}{l}1980-2002 \\
2003-2012\end{array}$ & $\begin{array}{l}\text { Permanent Household Survey - (Single survey) } \\
\text { Permanent Household Survey - (Series) }\end{array}$ \\
\hline Brazil & $1981-2011$ & Permanent Household Survey \\
\hline Chile & 1987-2011 & National Socioeconomic Survey \\
\hline Costa Rica & $\begin{array}{l}1989-2009 \\
2010\end{array}$ & $\begin{array}{l}\text { Multi-purpose Household Survey } \\
\text { National Household Survey }\end{array}$ \\
\hline El Salvador & $1991-2010$ & Multi-purpose Household Survey \\
\hline Honduras & $1990-2011$ & Multi-purpose Permanent Household Survey \\
\hline Mexico & $1989-2010$ & National Household Income and Expenditure Survey \\
\hline Uruguay & $1989-2011$ & Continuous Household Survey \\
\hline Venezuela (Bolivarian Republic of) & $1989-2011$ & Sample Household Survey \\
\hline
\end{tabular}

Source: prepared by the author on the basis of the Socio-Economic Database for Latin America and the Caribbean (sEDLAC) of the Center for Distributive, Labor and Social Studies (CEDLAs) and the World Bank.

TABLE A.2

Years used to compute weightings

(Early 1980-late 2000s)

\begin{tabular}{|c|c|c|c|c|c|c|c|c|c|c|}
\hline Period & Argentina & Brazil & Chile & Costa Rica & El Salvador & Honduras & Mexico & Panama & Uruguay & $\begin{array}{c}\text { Venezuela } \\
\text { (Bolivarian } \\
\text { Republic of) }\end{array}$ \\
\hline Early 1980s & 1980 & 1981 & $\ldots$ & $\ldots$ & $\cdots$ & $\ldots$ & $\ldots$ & $\cdots$ & $\cdots$ & $\ldots$ \\
\hline Late 1980 s & 1989 & 1989 & 1987 & 1989 & $\ldots$ & $\ldots$ & 1989 & 1989 & 1989 & 1989 \\
\hline Early 1990s & 1992 & 1992 & 1992 & 1992 & 1991 & 1992 & 1992 & 1991 & 1992 & 1992 \\
\hline Late $1990 \mathrm{~s}$ & 1998 & 1998 & 1998 & 1998 & 1998 & 1998 & 1998 & 1998 & 1998 & 1998 \\
\hline Early 2000s & 2003 & 2003 & 2003 & 2003 & 2003 & 2003 & 2002 & 2003 & 2003 & 2003 \\
\hline Late $2000 \mathrm{~s}$ & 2009 & 2009 & 2009 & 2009 & 2009 & 2009 & 2008 & 2009 & 2009 & 2009 \\
\hline
\end{tabular}

Source: prepared by the author on the basis of the Socio-Economic Database for Latin America and the Caribbean (sEDLAC) of the Center for Distributive, Labor and Social Studies (CEDLAs) and the World Bank. 


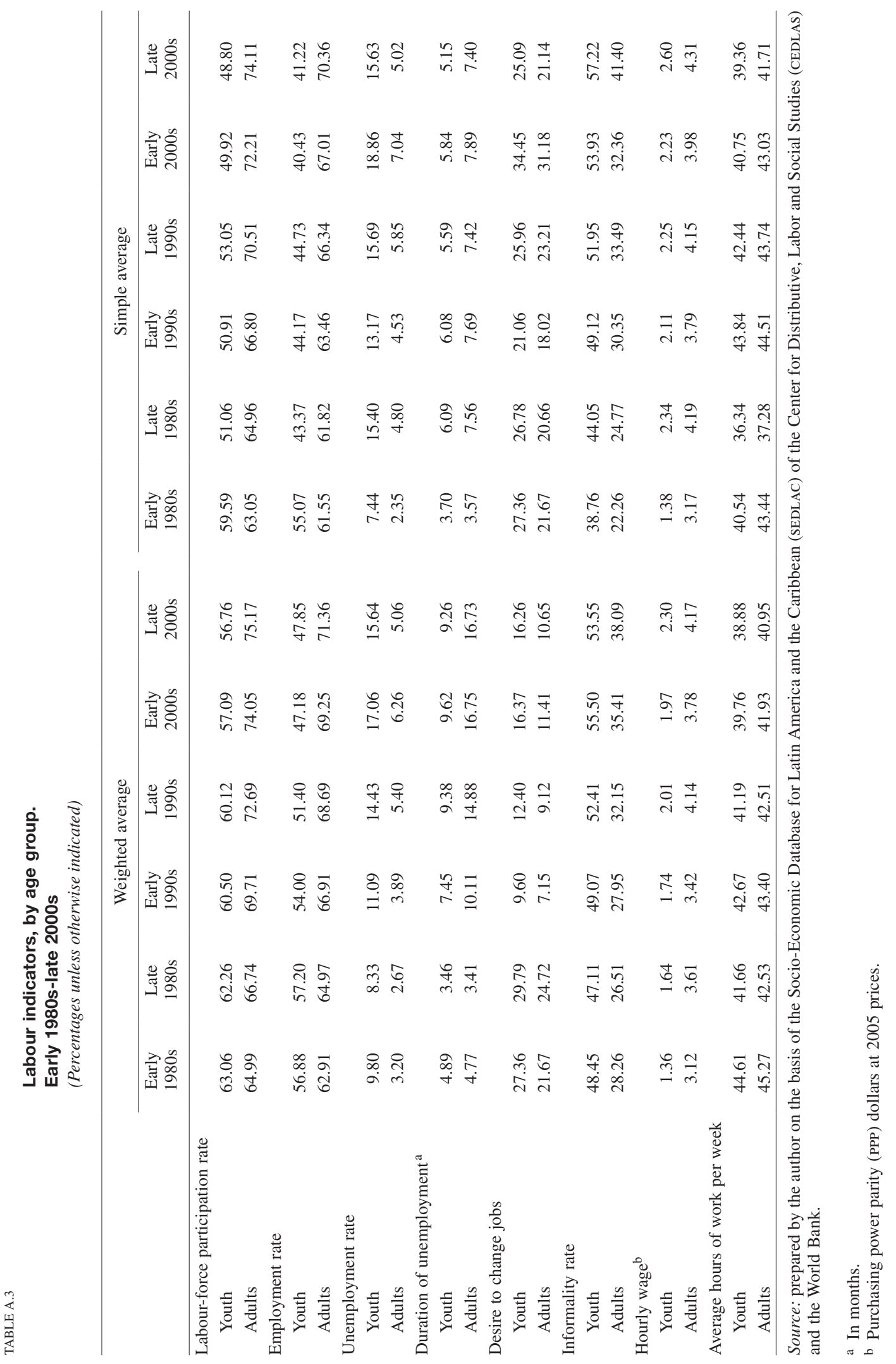




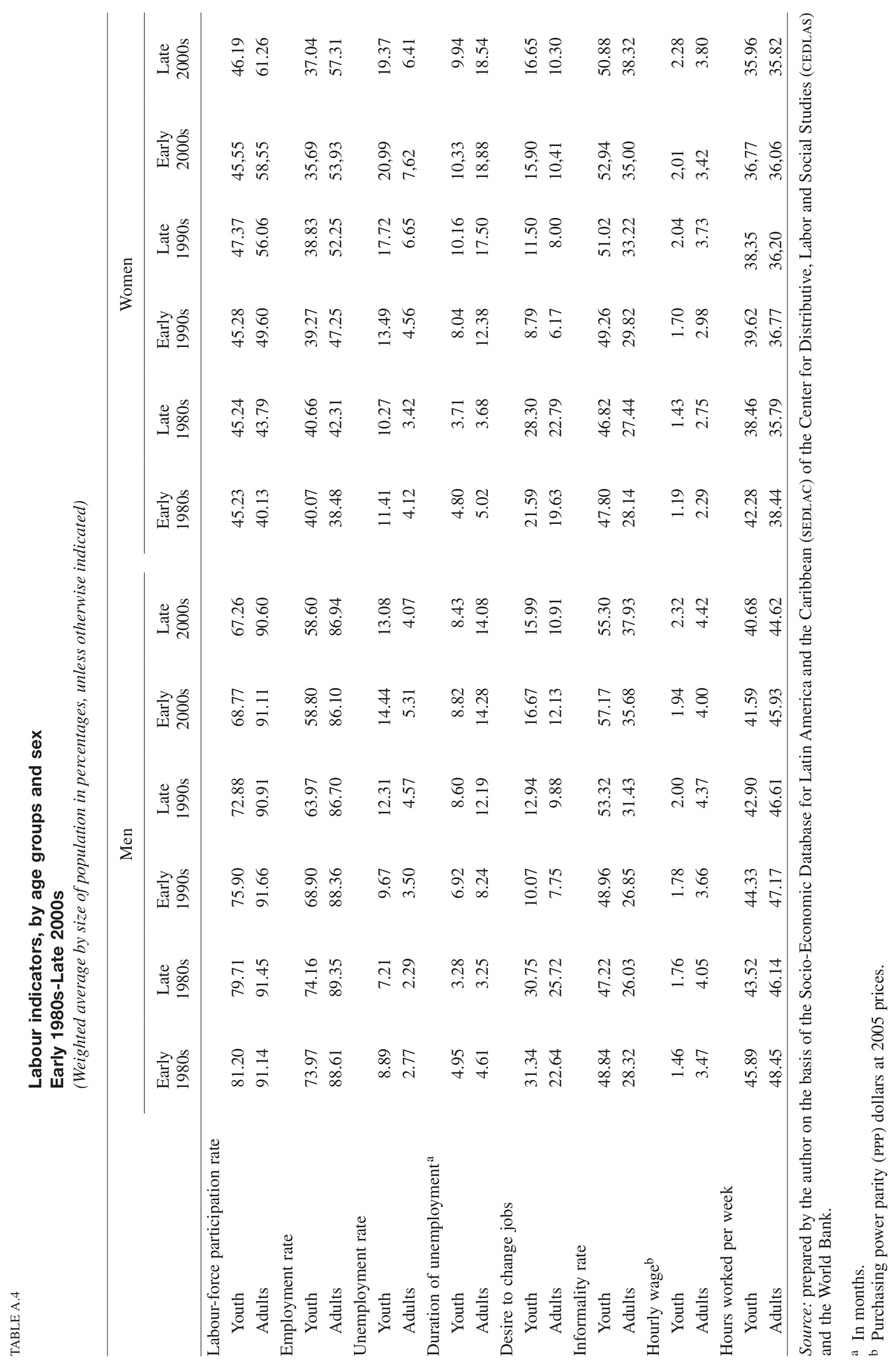




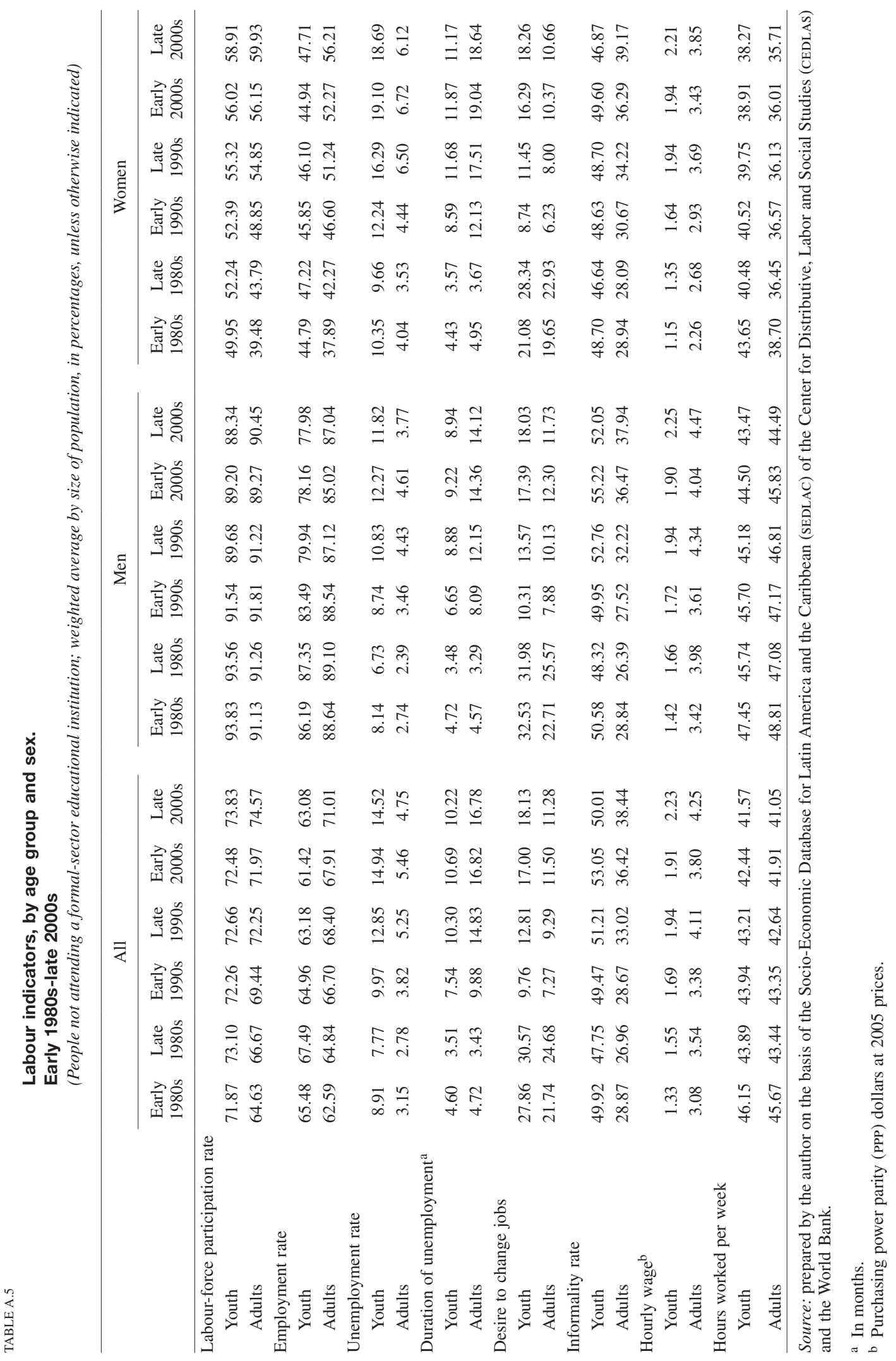




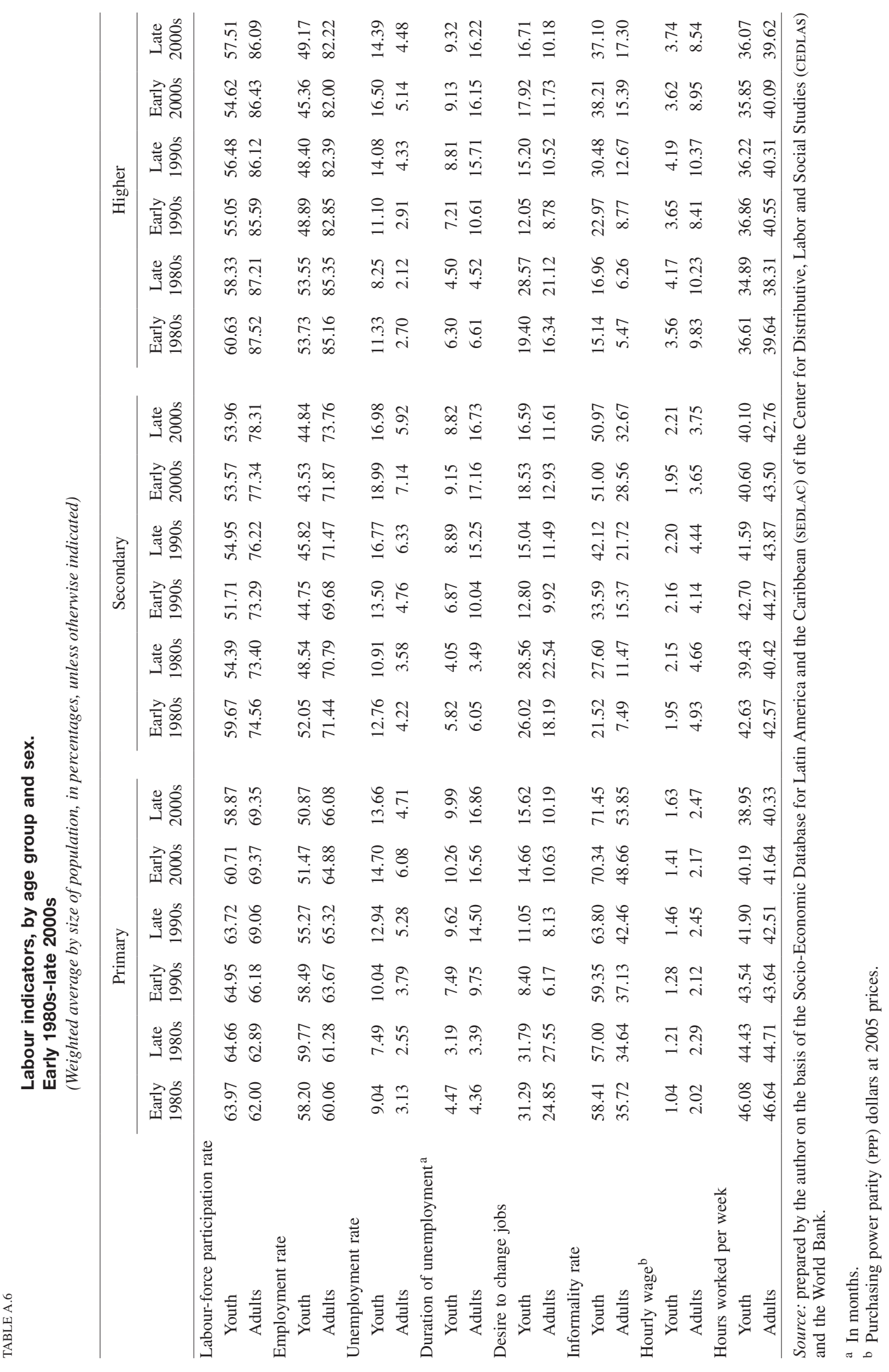




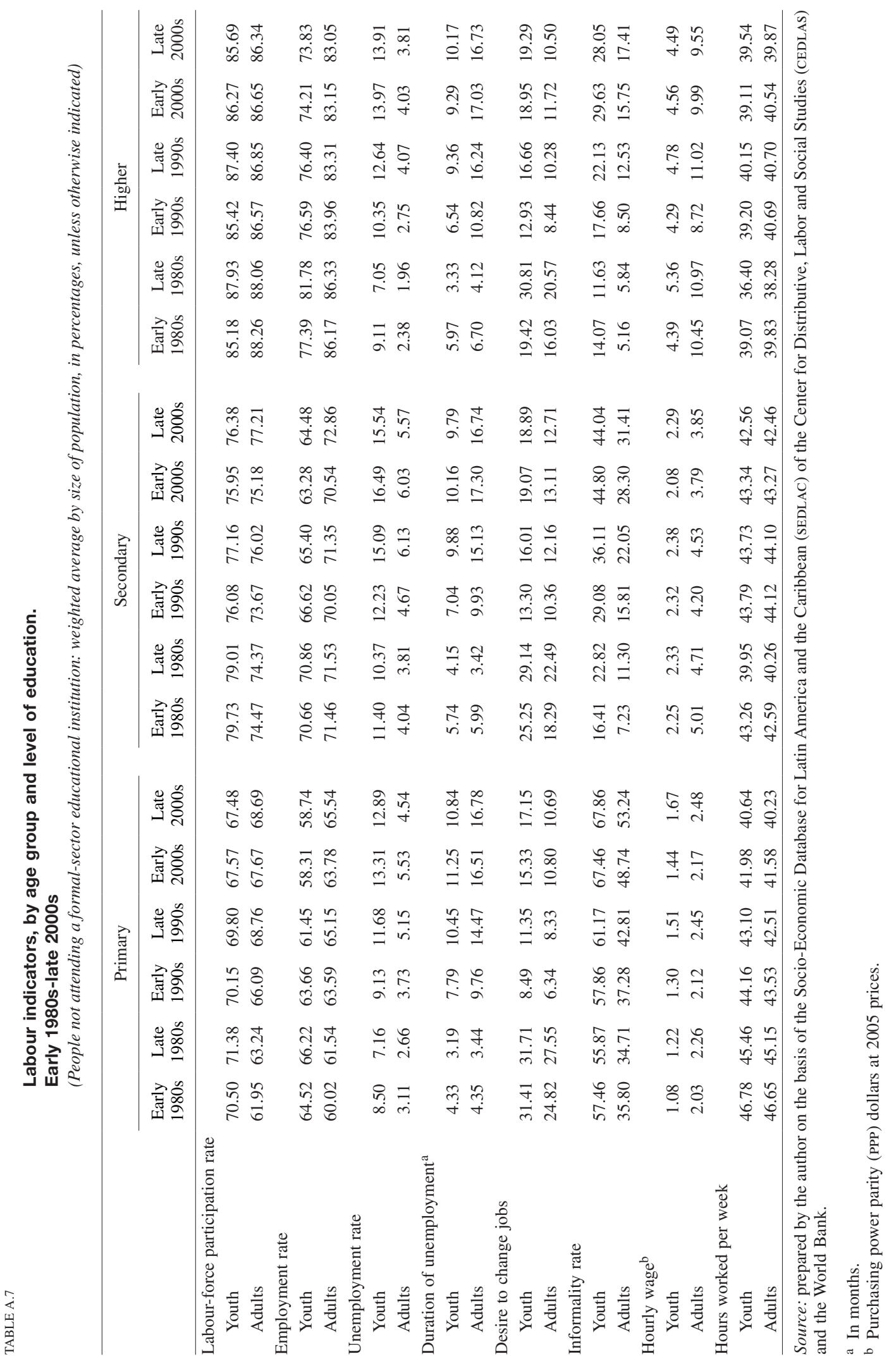




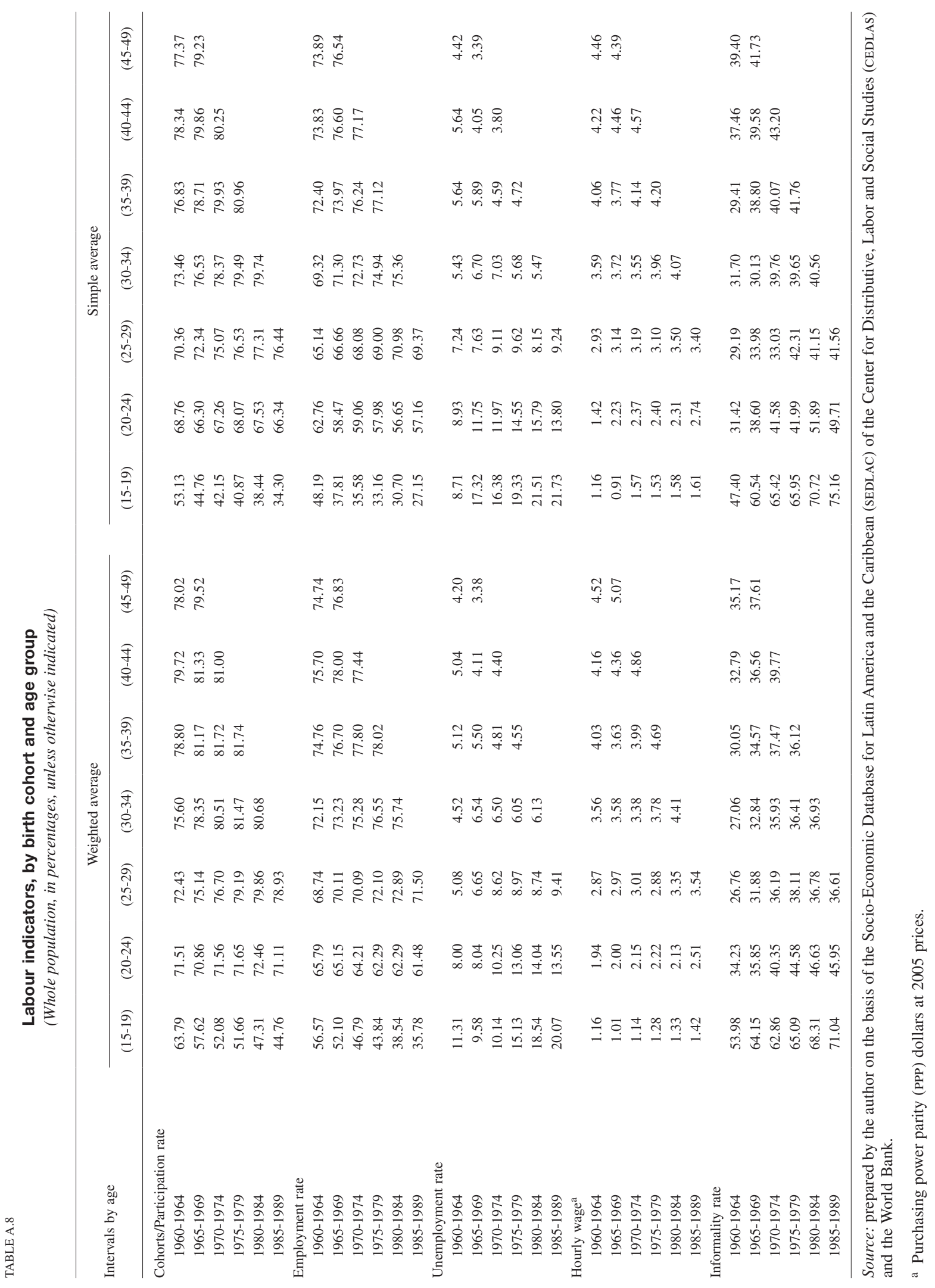




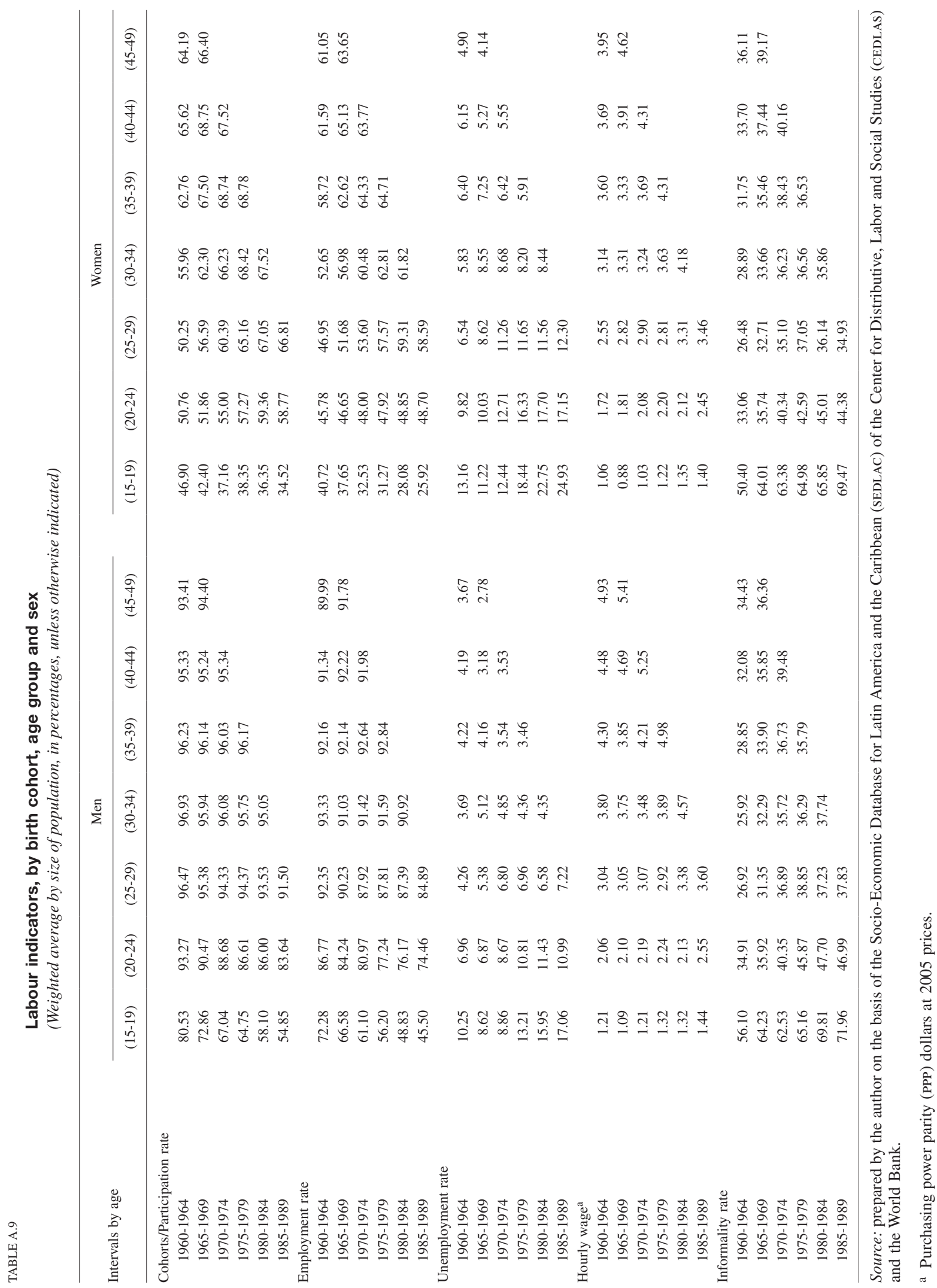




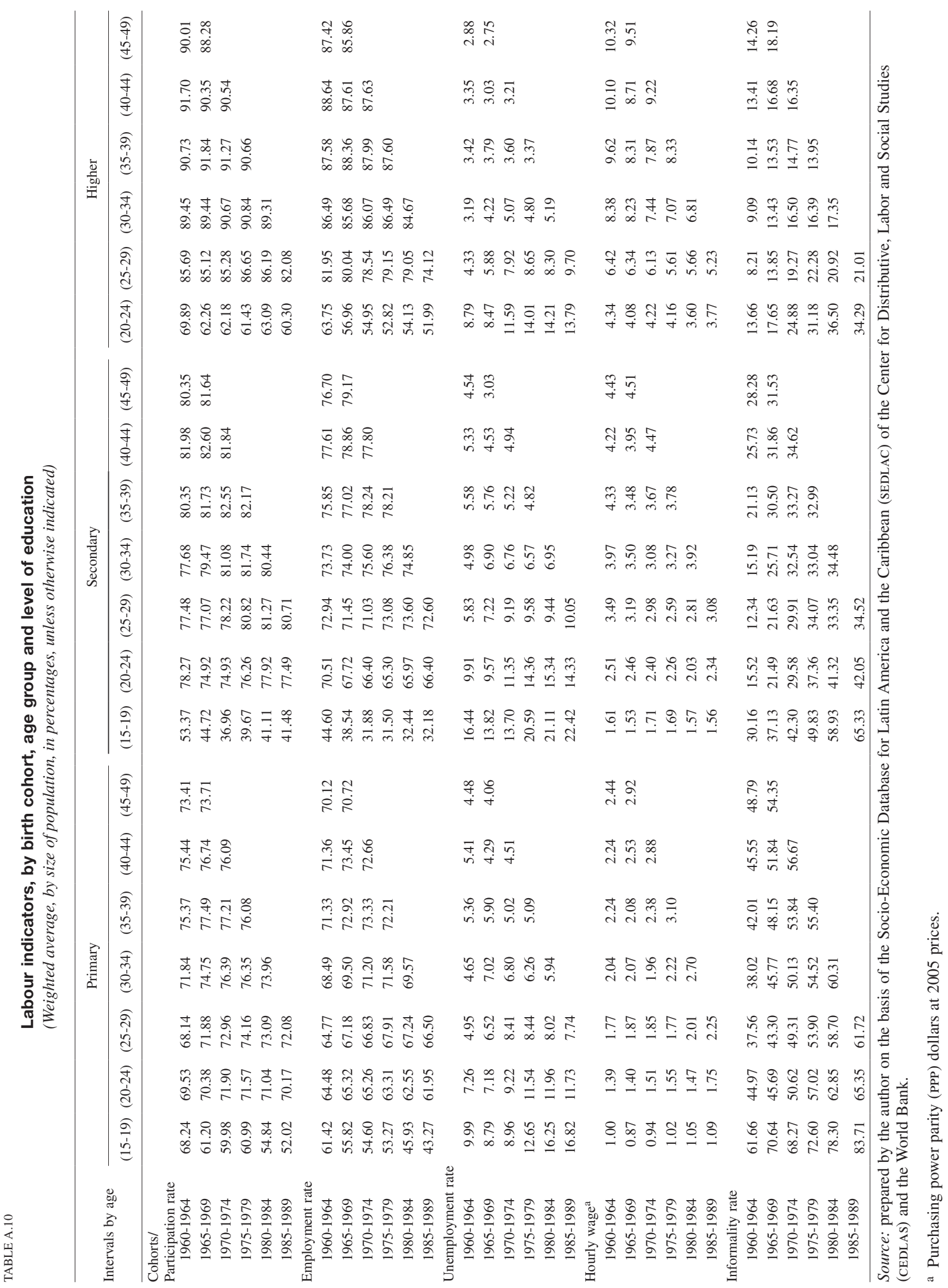




\section{Bibliography}

Bassi, M. and S. Galiani (2009), "Youth Labor Market in Latin America: A Descriptive Analysis", Washington, D.C., Inter-American Development Bank, unpublished.

Bell, D. and D. Blanchflower (2010), "Youth unemployment: déjà vu?", IZA Discussion Paper, No. 4705, Bonn, Institute for the Study of Labor, January.

Blanchflower, D. and R.B. Freeman (2000), "The declining economic status of young workers in OECD countries", Youth Employment and Joblessness in Advanced Countries, D.G. Blanchflower and R.B. Freeman (eds.), Cambridge, Massachusetts, National Bureau of Economic Research.

Bosch, M. and W. Maloney (2010), "Comparative analysis of labor market dynamics using Markov processes: an application to informality", Labour Economics, vol. 17, No. 4, Amsterdam, Elsevier.

Breen, R. (1992), "Job changing and job loss in the Irish youth labor market: a test of a general model", European Sociological Review, vol. 8, No. 2, Oxford, Oxford University Press.

Cárdenas, M., R. de Hoyos and M. Székely (2011), The Idle Youth in Latin America: A Persistent Problem in a Decade of Prosperity, Washington, D.C., The Brookings Institution.

CePalstat (Databases and Statistical Publications) (2012), July [online] http://www.eclac.org/estadisticas.

Cruces, G., A. Ham and M. Viollaz (2012), "Scarring Effects of Youth Unemployment and Informality: Evidence from Brazil", unpublished.

Cunningham, W. and J. Bustos (2011), "Youth employment transitions in Latin America", Policy Research Working Papers, No. 5521, Washington, D.C., World Bank.

Dolado, J., F. Felgueroso and J. Jimeno (2000), "Explaining youth labor market problems in Spain: crowding-out, institutions, or technology shifts?", IZA Discussion Paper, No. 142, Bonn, Institute for the Study of Labor, February.

ECLAC (Economic Commission for Latin America and the Caribbean) (2011), Social Panorama of Latin America 2010
(LC/G.2481-P), Santiago, Chile. United Nations publication, Sales No. E.11.II.G.6.

Fawcett, C. (2001), "Los jóvenes latinoamericanos en transición: Un análisis sobre el desempleo juvenil en América Latina y el Caribe", Documentos de Trabajo Mercado Laboral series, Washington, D.C., Inter-American Development Bank.

Marchionni, M., G. Bet and A. Pacheco (2007), "Empleo, educación y entorno social de los jóvenes: Una nueva fuente de información", Working Paper, No. 61, Center for Distributive, Labor and Social Studies (CEDLAS).

Maurizio, R. (2011), “Trayectorias laborales de los jóvenes en Argentina: ¿Dificultades en el mercado de trabajo o carrera laboral ascendente?", Macroeconomía del Desarrollo series, No. 109 (LC/L.3302-P), Santiago, Chile, Economic Commission for Latin America and the Caribbean (ECLAC). United Nations publication, Sales No. S.11.II.G.24.

(2010), "Enfoque de género en las instituciones laborales y las políticas del mercado de trabajo en América Latina", Macroeconomía del Desarrollo series, No. 104 (LC/L.3230-P), Santiago, Chile, Economic Commission for Latin America and the Caribbean (ECLAC). United Nations publication, Sales No. S.10.II.G.34.

Neumark, D. (2002), "Youth labor markets in the United States: shopping around vs. staying put", The Review of Economics and Statistics, vol. 84, No. 3, Cambridge, Massachusetts, The мIт Press

Neumark, D. and O. Nizalova (2007), "Minimum wage effects in the longer run", Journal of Human Resources, vol. 46, No. 2, Madison, University of Wisconsin Press.

SEDLAC (Socio-Economic Database for Latin America and the Caribbean) (2013) [online] http://sedlac.econo.unlp.edu.ar.

Weller, J. (ed.) (2006), Los jóvenes y el empleo en América Latina. Desafíos y perspectivas ante el nuevo escenario laboral, Santiago, Chile, Economic Commission for Latin America and the Caribbean (ECLAC).

World Bank (2012), World Development Indicators, Washington, D.C. 